\title{
Biomimetic Elastin-Like Polypeptides as Materials for the Activation of Mechanophoric Catalysts
}

\author{
Sebastian Funtan ${ }^{a}(D)$ \\ Anne Funtan ${ }^{b}$ (D) \\ Reinhard Paschke ${ }^{b}$ \\ Wolfgang $\mathrm{H}$. Binder*a (i) \\ ${ }^{a}$ Macromolecular Chemistry, Institute of Chemistry, Faculty of Natural Science II, \\ Martin Luther University Halle-Wittenberg, Von-Danckelmann-Platz 4, 06120 Halle \\ (Saale), Germany \\ Biozentrum, Martin Luther University Halle-Wittenberg, Weinbergweg 22, 06120 \\ Halle (Saale), Germany \\ wolfgang.binder@chemie.uni-halle.de
}

\section{Received: 26.11.2019 \\ Accepted after revision: 31.12 .2019 \\ DOI: 10.1055/s-0040-1702149; Art ID: 190023 License terms: (C)}

(c) 2019. The Author(s). This is an open access article published by Thieme under the terms of the Creative Commons Attribution-NonDerivative-NonCommercial-License, permitting copying and reproduction so long as the original work is given appropriate credit. Contents may not be used for commercial purposes, or adapted, remixed, transformed or built upon. (https://creativecommons.org/licenses/by-nc-nd/4.0/).

Abstract Elastin-like polypeptides (ELPS) are well known for their elastic and thermoresponsive behaviors. Their elasticity originates from the formation of a $\beta$-spiral which is the consequence of stacking type-II $\beta$-turns, formed from individual VPGVG pentapeptide units. Here, the synthesis of ELPs of varying chain lengths [VPGVG, (VPGVG) 2 , and $(\mathrm{VPGVG})_{4}$ ] and their coupling to a mechanoresponsive catalyst are reported. The attached ELP chains can act as "molecular springs," allowing for an efficient uptake and transmission of an applied force to the mechanophoric bond. This leads to stress-induced activation of the mechanophoric catalyst, in turn transforming mechanical energy into a "click" reaction. Secondary structure analysis via IR and CD spectroscopy revealed that the $\beta$-spiral formation of the ELP is not affected by the coupling process and the $\beta$-spiral is still intact in the mechanocatalyst after the coupling. Mechanochemical activation of the synthesized catalysts by an external applied force, studied via ultrasonication, showed conversions of the copper(I)-catalyzed alkyne-azide "click" reaction (CuAAC) up to $5.6 \%$ with an increasing chain length of the peptide, proving the potential to incorporate this chemistry into biomaterial engineering.

Key words Elastin-like polypeptides, $\beta$-spiral, peptide coupling, copper(I), "click" reaction, mechanochemistry, mechanocatalysts

\section{Introduction}

Elastin-like polypeptides (ELPs) are artificial derivatives of elastin, a highly cross-linked, extracellular matrix protein, that is responsible for elasticity and resilience of tissues that repeatedly undergo extension and retraction such as ligaments and arteries. ${ }^{1-5}$ ELPs consist of short amino

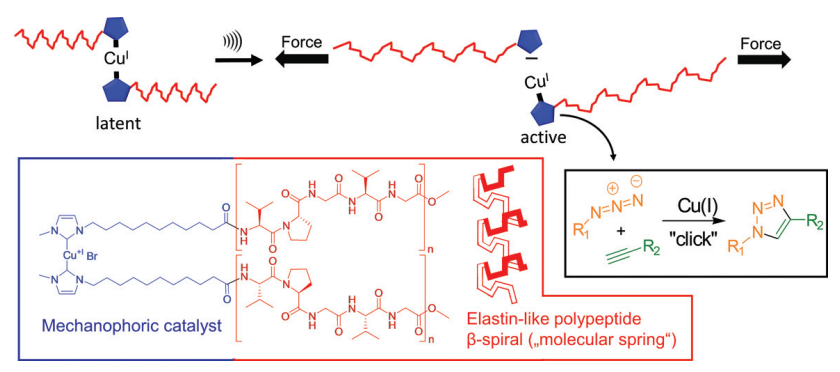

acid sequences, being part of the elastin sequence, whose polymerization leads to polypeptides with similar thermoresponsive and elastic (when cross-linked) behaviors compared to native elastin. ${ }^{6,7}$ The pentapeptide VPGVG is of special interest because it is the most prominent amino acid sequence of native elastin. ${ }^{8,9}$ While native elastin is insoluble due to cross-linking, ELPs as a soluble alternative to elastin allowed detailed investigation of the origin of elasticity and this led to the development of the fibrillar model. ${ }^{10-15}$ Using the VPGVG sequence it was found that each pentapeptide unit forms a type-II $\beta$-turn independently from the other units. ${ }^{10,16-18}$ Several $\beta$-turns will stack on each other, leading to the formation of a loose helix, also called $\beta$-spiral. The $\beta$-spiral is kinetically free to undergo librational or rocking motions, but stretching dampens these motions and the number of states of equivalent energy is drastically reduced, in turn providing the restoring force for elasticity. ${ }^{12}$

Since an efficient force transmission plays a crucial role in the field of mechanochemistry, ELPs are perfectly tailored to take up and redirect an applied force to the mechanophoric bond, thus acting as "molecular springs."12,19,20 Mechanophores contain one or more mechanically labile bonds, functional groups that are inactive in their initial state but can respond to an external applied force. Once activated, mechanophores can undergo a variety of mechanochemical transformations such as color changes, ${ }^{21-23}$ chemiluminescence, $^{24,25}$ activation of latent metal catalysts, ${ }^{26-34}$ biased reactivity, ${ }^{35}$ release of small molecules, ${ }^{36,37}$ generation of protons, ${ }^{38}$ and also remodeling of polymers. ${ }^{39}$ Besides the correct positioning of the mechanophoric bond near the center of the molecule, the attached polymer chains play a crucial role since they take up and transmit the force along the polymer backbone. ${ }^{40,41}$ We previously have designed latent $\mathrm{Cu}(\mathrm{I})$ bis( $\mathrm{N}$-heterocyclic carbene) (NHC) catalysts as mechanophores for the time- and spatial-controlled copper(I)catalyzed alkyne-azide "click" reaction (CuAAC). ${ }^{28,29,31,33}$ The ability of the attached polymer chains to transmit an applied force was controlled via the $T_{\mathrm{g}}$ of the chosen polymer 
<smiles>CN1C=CN(CCCCCCCCCCCC(=O)O)C1[C](Br)C1N(C)C=CN1CCCCCCCCCCC(=O)O</smiles><smiles>CN1C=CN(CCCN)C1[C+](Br)C(Br)C1N(C)C=CN1CCCN</smiles>

Figure 1 The bifunctional mechanocatalysts bearing either two carboxyl or two amino groups are used for coupling reactions via the $\mathrm{N}$ - or the $\mathrm{C}$-terminus of peptides.

[poly(isobutylene), poly(styrene), and poly(tetrahydrofuran)]. Exchanging the synthetic polymer handles with peptides thus is a promising way to study force transmission, since the resulting $\beta$-spiral structures could be exploited as "molecular springs."

As published previously, in the first step, two lowmolecular weight $\mathrm{Cu}(\mathrm{I})$ bis(NHC) mechanophoric catalysts bearing either two carboxyl groups $\left\{\left[\mathrm{Cu}\left(\mathrm{C}_{10} \mathrm{COOH}-\mathrm{NHC}\right)_{2}\right]\right.$ $\mathrm{Br}\}$ (1) or two amino groups $\left[\mathrm{Cu}\left(\mathrm{C}_{3} \mathrm{NH}_{2}-\mathrm{NHC}\right)_{2} \mathrm{Br}\right]$ (2) (see Figure 1) were designed, enabling peptide coupling reactions with the $\mathrm{N}$ - or the $\mathrm{C}$-terminus of peptides. ${ }^{42}$ The first few reactions revealed a persisting mechanophoric behavior after coupling of single amino acids (Gly and Val).

In the present article, we stepwise extended the amino acid sequence [VG, VPG, VPGVG, $(\mathrm{VPGVG})_{2}$, and $(\mathrm{VPGVG})_{4}$ ] and coupled it to the latent mechanophoric $\mathrm{Cu}(\mathrm{I})$ bis(NHC) complexes 1 and 2, yielding mechanophores with varying peptide chain lengths. In addition to the linear catalysts, resulting from the coupling of $\mathbf{1}$ with the $\mathrm{N}$-terminusdeprotected peptides, we also generated chain-extended structures. Therefore, $\mathbf{1}$ and $\mathbf{2}$ were polymerized with the $C$ and $\mathrm{N}$-terminus-deprotected VPGVG sequence. Secondary structure analysis via IR and CD spectroscopy were conducted to probe whether the conformation of the peptide is affected by the coupling to the mechanophoric catalyst. Subsequently, ultrasonication was used to investigate the mechanochemical activation of all synthesized peptide-bearing catalysts by an external applied force.

\section{Results and Discussion}

The (VPGVG) 4 sequence was built up via solution-phase peptide synthesis, starting from the single amino acids shown in Scheme 1, following common coupling protocols. ${ }^{43}$ The tert-butoxycarbonyl (Boc) protecting group was used for the $N$-terminus, while the $C$-terminus was methyl ester (OMe) protected to ensure that it follows an orthogonal protectinggroup strategy. In the first step, glycine methyl ester hydrochloride (3), $N$-(tert-butoxycarbonyl)-L-proline (4), and $N$-(tert-butoxycarbonyl)-L-valine (5) were synthesized. Coupling of $\mathbf{3}$ and $\mathbf{5}$ using the common peptide coupling agents 1-ethyl-3(3-dimethylaminopropyl)carbodiimide hydrochloride (EDC. $\mathrm{HCl}$ ) and 1-hydroxybenzotriazole (HOBt) yielded the dipeptide $\mathbf{6}$, which was then deprotected with trifluoroacetic acid (TFA) to generate the $\mathrm{N}$-terminus-deprotected dipeptide 7. Coupling of $\mathbf{3}$ and $\mathbf{4}$ generated the dipeptide $\mathbf{8}$, which was also $\mathrm{N}$-terminus-deprotected, in turn generating 9. Subsequent coupling with $\mathbf{5}$ led to the formation of the tripeptide 10, which was dissolved in $\mathrm{H}_{2} \mathrm{O}$ and THF (4:3) and stirred in the presence of lithium hydroxide to obtain the $C$-terminus-deprotected tripeptide $\mathbf{1 1 . 1 0}$ was also deprotected at the $N$-terminus to yield peptide 12, which later was coupled to the mechanophoric catalyst 1. Coupling of 7 and $\mathbf{1 1}$ generated the pentapeptide 13, which is known to be one of the most important ELP sequences. ${ }^{4}$ The ${ }^{1} \mathrm{H}$ NMR spectrum of 13 is shown in Figure $2 \mathrm{c}$ (for ${ }^{1} \mathrm{H}$ and ${ }^{13} \mathrm{C}$ NMR spectra of the other peptides, see the Supporting Information), proving that both protection groups are still present after the

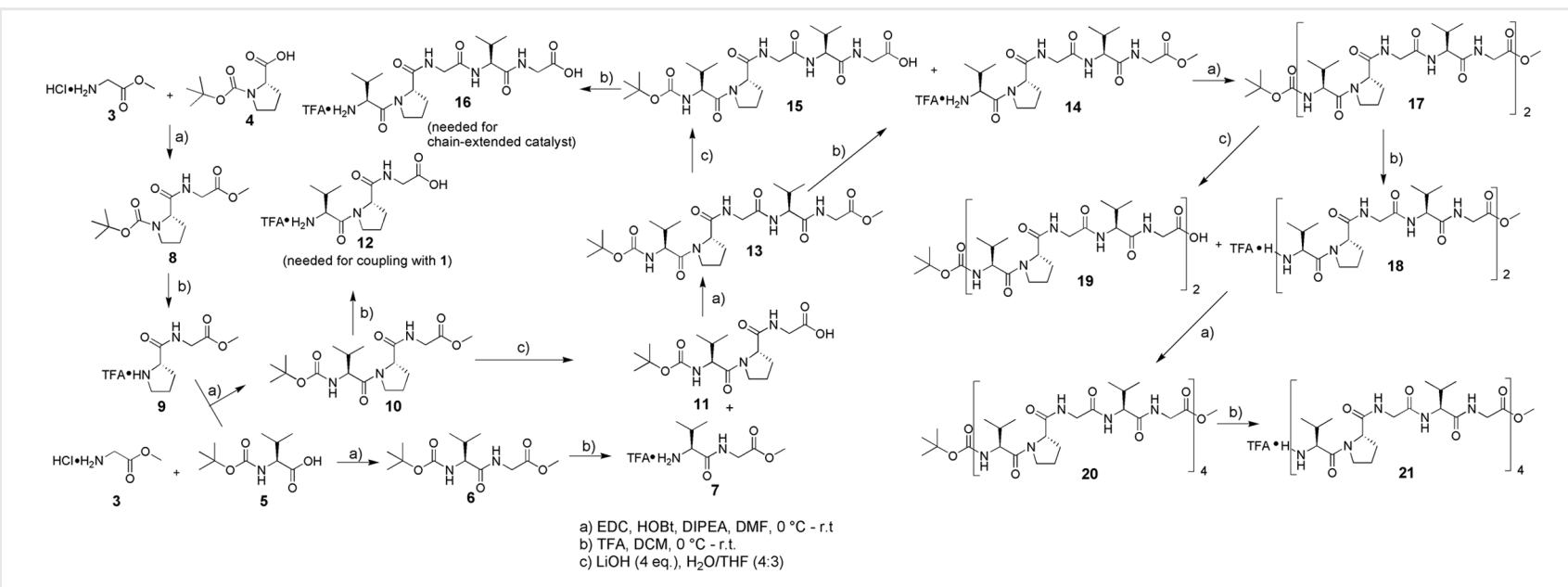

Scheme 1 Synthetic approach for the elastin-like polypeptide sequence starting from single amino acids. $C$ - and $N$-terminus protection steps for the single amino acids are not shown. 


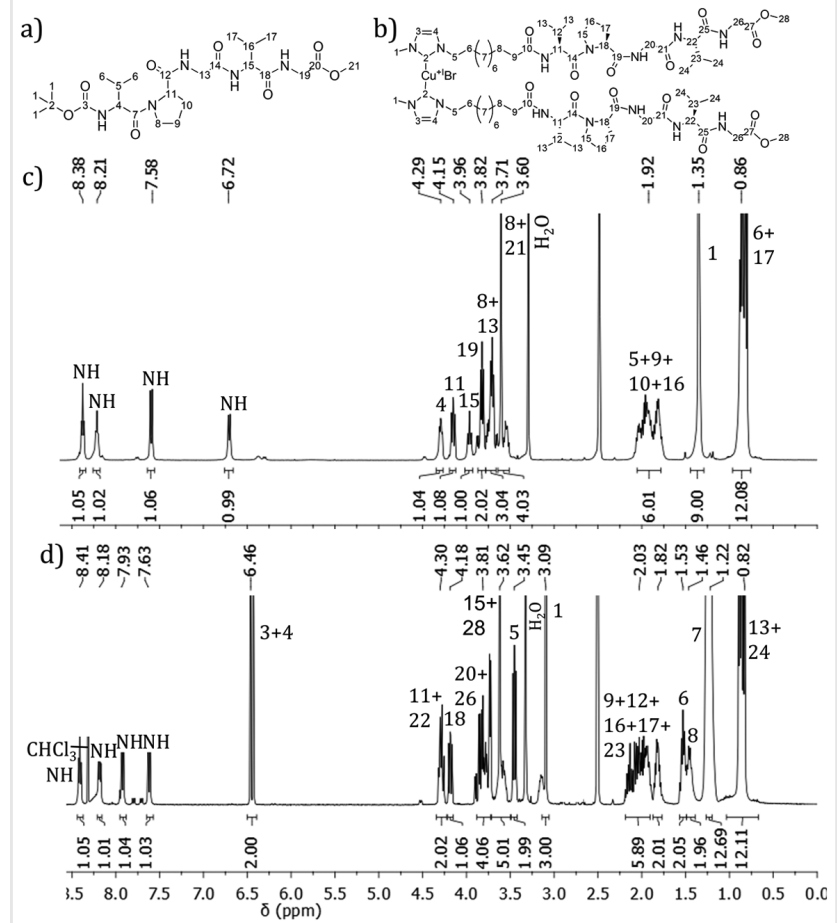

Figure 2 Chemical structures of (a) pentapeptide $\mathbf{1 3}$ and (b) the mechanophoric catalyst 22c bearing the pentapeptide. ${ }^{1} \mathrm{H}$ NMR spectra of (c) pentapeptide 13 and (d) the mechanophoric catalyst 22c bearing the pentapeptide.

coupling. The Boc group gave a resonance at $1.35 \mathrm{ppm}$, while the methyl ester group could be assigned to the signal at $3.60 \mathrm{ppm}$, overlapping with proton $\mathrm{H}-8$. Splitting product 13 to deprotect the $\mathrm{N}$-terminus of one half and the $\mathrm{C}$-terminus of the other half generated peptides 14 and 15, which afterwards could be coupled to obtain the decapeptide 17. A small portion of peptide $\mathbf{1 5}$ was also deprotected at the $\mathrm{N}$-terminus, generating the double-deprotected peptide 16, which subsequently was used for the synthesis of the chain-extended catalyst. Once more splitting of peptide 17 followed by $N$ - and $C$-terminus protection yielded peptides 18 and $\mathbf{1 9}$, which were subsequently coupled to the eicosapeptide $\mathbf{2 0}$. Stirring $\mathbf{2 0}$ in the presence of TFA generated $\mathbf{2 1}$ with an unprotected $N$-terminus.

In the next step, peptide coupling reactions were performed to couple the peptides $7, \mathbf{1 2}, \mathbf{1 4}, \mathbf{1 8}$, and 21 to 1 , yielding the mechanophoric catalysts $\mathbf{2 2 a}$-e as shown in Scheme 2. 22f was generated by polycondensation of $\mathbf{1 6}$ with $\mathbf{1}$ and 2, leading to polymeric structures with molecular weights of up to $4500 \mathrm{~g} \mathrm{~mol}^{-1}$ [see the Supporting Information for gel permeation chromatography (GPC) trace]. For the coupling reactions, $N, N^{\prime}$-dicyclohexylcarbodiimide (DCC) and pentafluorophenol were chosen as reagents due to the higher yields in comparison to $\mathrm{EDC} \cdot \mathrm{HCl}$ and $\mathrm{HOBt}$, as reported previously. ${ }^{42}$ While the shorter peptides $\mathbf{7}$ and $\mathbf{1 2}$ were still soluble in dichloromethane (DCM), dimethylformamide (DMF) was chosen as a solvent for the longer peptides 14 , $\mathbf{1 6}, \mathbf{1 8}$, and 21. Figure $2 \mathrm{~d}$ shows the ${ }^{1} \mathrm{H}$ NMR of 22c after the workup, which proved that the catalyst was not destroyed during the coupling process (for ${ }^{1} \mathrm{H}$ and ${ }^{13} \mathrm{C}$ NMR of the other catalyst-peptide conjugates, check the Supporting Information). Destruction of the catalyst would lead to a resonance at $\sim 10.50$ ppm due to destruction of the copper-carbene bond, leading to reprotonation of $\mathrm{C}-2$ (for the full ${ }^{1} \mathrm{H}$ NMR spectrum, see the Supporting Information). Furthermore, matching integrals for both signals $\left\{\left[\mathrm{Cu}\left(\mathrm{C}_{10} \mathrm{COOH}-\mathrm{NHC}\right)_{2}\right] \mathrm{Br}\right.$ and pentapeptide proved a quantitative coupling reaction.

Since the peptides were coupled to the mechanophore with the aim to exploit their "molecular spring" behavior, it was essential to check if the coupling affected the ability of the peptide to form the $\beta$-spiral. We therefore performed IR and CD investigations to obtain information about the secondary structure of pentapeptide $\mathbf{1 3}$ and compared the obtained

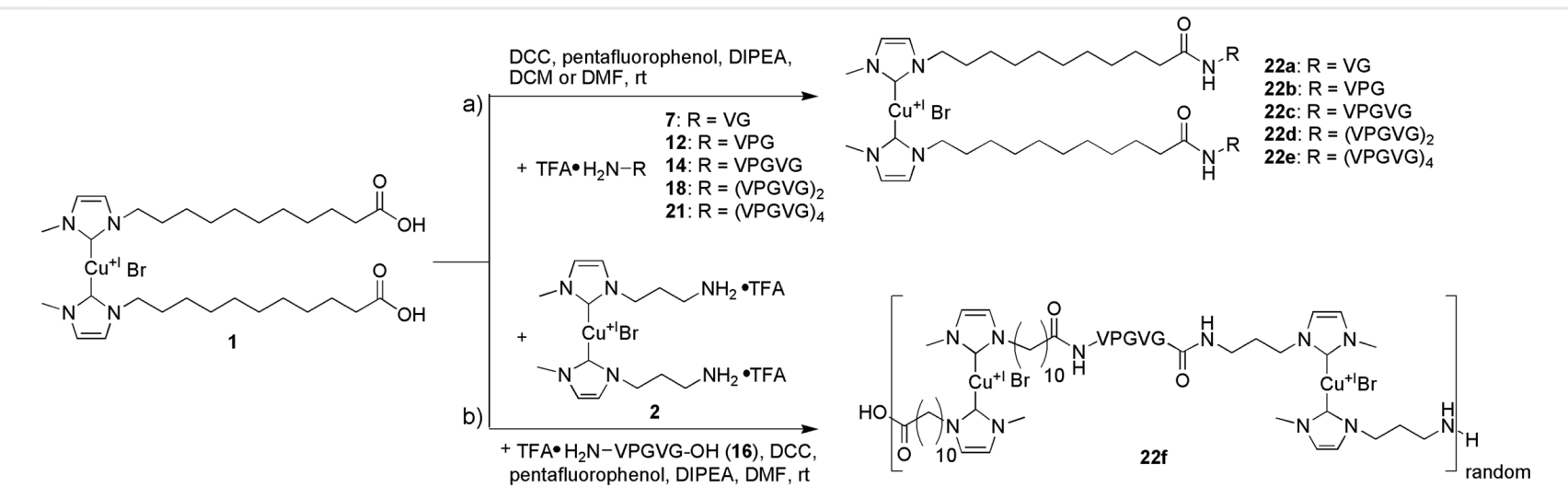

Scheme 2 Synthetic approach for the coupling of the ELP sequences to the mechanophoric catalysts. (a) Coupling of the $N$-terminus-deprotected peptides with varying chain lengths to 1 . (b) Polycondensation of 1,2 , and the $N$ - and $C$-terminus-deprotected pentapeptide 16 generates the chainextended catalyst $22 \mathrm{f}$. 

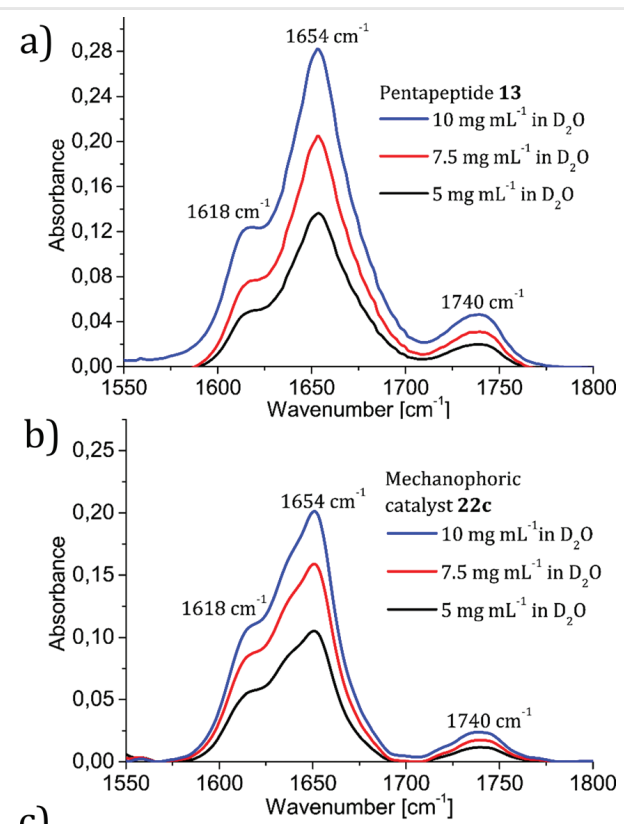

C)

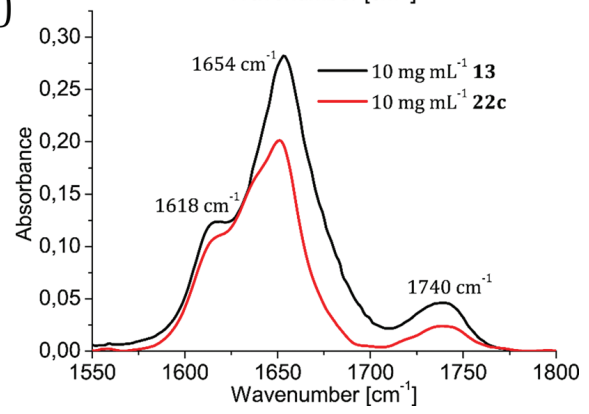

Figure 3 IR spectra (amide I band) measured in $\mathrm{D}_{2} \mathrm{O}$ at three different concentrations $\left(5,7.5\right.$, and $10 \mathrm{mg} \mathrm{mL}^{-1}$ ) of (a) 13 and (b) 22c. (c) Overlay of the IR spectra of $\mathbf{1 3}$ and $\mathbf{2 2 c}$ measured at a concentration of $10 \mathrm{mg} \mathrm{mL}^{-1}$.

results with those of the mechanophoric catalyst 22c, which also bears the pentapeptide sequence. IR analysis of the amide I band (1600-1690 $\left.\mathrm{cm}^{-1}\right)$ is frequently used to gain information about the secondary structure of peptides. ${ }^{44}$ The measurements were performed in $\mathrm{D}_{2} \mathrm{O}$ since it does not show any absorption in this region, in contrast to $\mathrm{H}_{2} \mathrm{O}(\mathrm{H}-\mathrm{O}-\mathrm{H}$ bending at $\left.1645 \mathrm{~cm}^{-1}\right)$. Within the amide I band, the IR of 13 showed two maxima at 1654 and $1618 \mathrm{~cm}^{-1}$ as shown in Figure 3a. It was previously reported by Franzen et al. that this double-peaked amide I band is the signature for the $\beta$-spiral and should not mistakenly be assigned to a $\alpha$-helical structure (usually occurring at $\left.1653 \pm 3 \mathrm{~cm}^{-1}\right) .{ }^{44,45}$ Formation of the $\beta$-spiral was observed at three concentrations $\left(10,7.5\right.$, and $\left.5 \mathrm{mg} \mathrm{mL}^{-1}\right)$. Normalization of the IR spectra to the maximum at $1740 \mathrm{~cm}^{-1}$ (originating from the methyl ester protection group) revealed that the formation of the $\beta$-spiral was not influenced within the tested concentration range (see the Supporting Information). Coupling of the pentapeptide to the mechanophoric catalyst did not influence the $\beta$-spiral formation as shown in the amide I band from 22c in Figure 3b. The double-peaked spectrum with two maxima at 1618 and $1654 \mathrm{~cm}^{-1}$ was still visible for the mechanophoric catalyst. IR spectra were recorded at the same concentrations (10,7.5, and $5 \mathrm{mg} \mathrm{mL}^{-1}$ ) as done for 13 . Normalization to the maximum at $1740 \mathrm{~cm}^{-1}$ again showed that $\beta$-spiral formation was not influenced in the tested concentration range (see the Supporting Information). Overlaying the two measurements of 13 and $22 \mathrm{c}$ at $10 \mathrm{mg} \mathrm{mL}^{-1}$ clearly showed that there was no shift in the absorbance maxima after the coupling reaction, as shown in Figure $3 c$. It is noteworthy that the $\beta$-spiral formation was not disturbed if two pentapeptide units were linked together via the mechanophore (22c). As demonstrated earlier by Guan and Chen, each pentapeptide unit forms the $\beta$-spiral structure independently from other pentapeptide units. ${ }^{43}$ To ensure that the "molecular spring" behavior of the peptide is the result of a $\beta$-spiral and not of an $\alpha$-helix, we also measured CD spectroscopy of $\mathbf{1 3}$ and $\mathbf{2 2 c}$, to obtain further information about the secondary structure of the peptides. ${ }^{46} \mathrm{CD}$ measurements were performed in $\mathrm{D}_{2} \mathrm{O}$ at concentrations of $0.4 \mathrm{mg} \mathrm{mL}^{-1}$ and the results are shown in Figure 4. The measurement results for 13 , showing one maximum at $208 \mathrm{~nm}$ and one minimum at $226 \mathrm{~nm}$, clearly indicated the presence of a $\beta$-sheet as the only secondary-structure element, while there was no evidence for the presence of $\alpha$-helical secondary structures. Similar to the IR spectroscopy results, the $C D$ spectrum of $\mathbf{2 2 c}$ was identical to that of $\mathbf{1 3}$, still showing only $\beta$-sheet conformation and no $\alpha$-helical structures. Accordingly, an adoption of a $\beta$-spiral structure could be concluded for the pentapeptide sequence. Coupling to the $\left[\mathrm{Cu}\left(\mathrm{C}_{10} \mathrm{COOH}-\mathrm{NHC}\right)_{2}\right] \mathrm{Br}$ mechanophore did not prevent the secondary structure formation, thus allowing the coupled peptide sequence to act as a "molecular spring."

We subsequently tested the mechanoresponsive behavior of the synthesized mechanophoric catalysts 22a-f using a model CuAAC "click" reaction between benzyl azide (23)

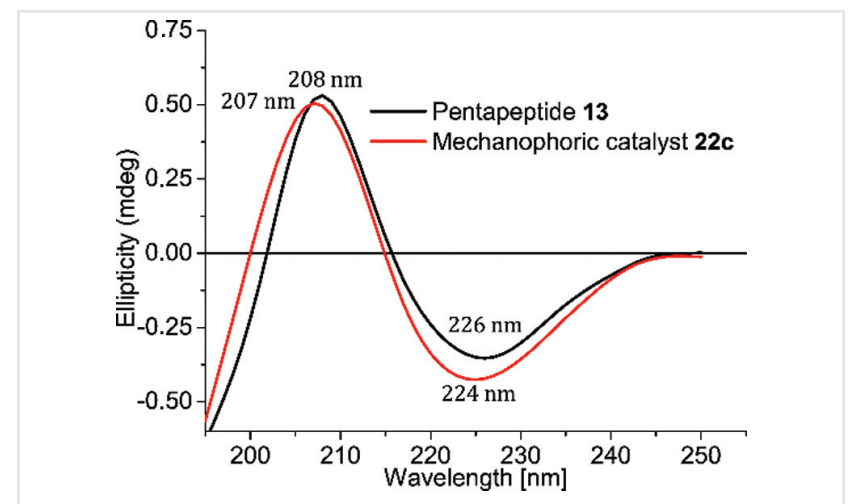

Figure $4 \mathrm{CD}$ spectra of $\mathbf{1 3}$ and $\mathbf{2 2 c}$ measured in $\mathrm{D}_{2} \mathrm{O}$ at a concentration of $0.4 \mathrm{mg} \mathrm{mL}^{-1}$. 
and phenylacetylene (24). The switching of latent $\mathrm{Cu}(\mathrm{I})$ bis (NHC) complexes to their active state after exposure to mechanical stress, for example in the form of ultrasound (in solution) or compression (in bulk), has been previously described. $^{28,29,31,33,42}$ While in its latent state, the $\mathrm{Cu}(\mathrm{I})$ center is shielded by the two NHC ligands, preventing the alkyne from coordination to the $\mathrm{Cu}(\mathrm{I})$. Once an external force is applied, one of the NHC ligands is cleaved off from the $\mathrm{Cu}(\mathrm{I})$ center due to the rupture of the copper-carbene bond. The exposed $\mathrm{Cu}(\mathrm{I})$ center is no longer shielded from the alkyne, in turn allowing the formation of the copper acetylide, which is known to be a crucial step in the "click" reaction (Figure 5). ${ }^{47}$ Activation of the catalyst to its monocarbene form was observed by following the "click" reaction of 23 and 24 via ${ }^{1} \mathrm{H}$ NMR spectroscopy. Therefore, samples were taken after the 3rd, 5th, 10th, 14th, and 17th cycles of ultrasonication. Calculation of the "click" conversion in dependence of the sonication time was done by observing the shifts from the methylene group of $\mathbf{2 3}$ from 4.35 to 5.59 ppm for the "click" product 25 as well as an increasing triazole resonance at $8.11 \mathrm{ppm}$. Activation of the latent catalyst could also be followed by observing the decreasing resonances of the NHC protons ( $\mathrm{H}-3$ and $\mathrm{H}-4)$ with proceeding ultrasonication cycles. Calculation for catalyst 22c is shown exemplary in the Supporting Information and activation was found to be $\sim 30 \%$ after the last cycle.

Ultrasonication experiments revealed that a stepwise extension of the attached peptide chain to the mechanophoric catalyst led to an increase of its catalytic activity (for a tabular overview including control experiments without ultrasonication, check the Supporting Information). Thus, the "click" conversion could be increased from $3.4 \%$ for catalyst $1\left\{\left[\mathrm{Cu}\left(\mathrm{C}_{10} \mathrm{COOH}-\mathrm{NHC}\right)_{2}\right] \mathrm{Br}\right\}$, which does not bear a peptide chain, to $5.6 \%$ for the catalyst with the longest peptide chain 22e $\left\{\left[\mathrm{Cu}\left(\mathrm{C}_{10} \mathrm{COOH}-(\mathrm{VPGVG})_{4}-\mathrm{NHC}\right)_{2}\right] \mathrm{Br}\right\}$. The chain-extended catalyst $\mathbf{2 2 f}$, bearing the pentapeptide moiety between the mechanophoric units, showed a slightly lower activity in comparison to $22 \mathbf{e}$ with a conversion of $4.7 \%$.

In order to test the biocompatibility of the synthesized catalysts, we also performed cytotoxicity tests for two

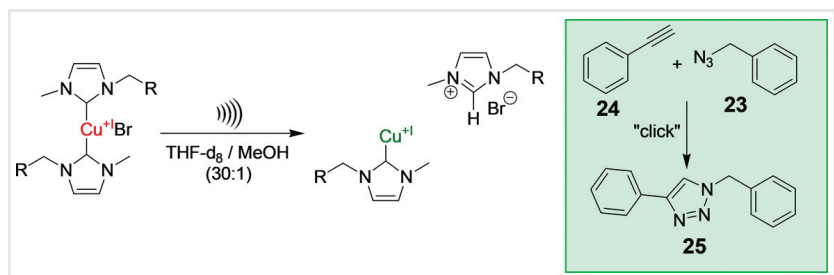

Figure 5 The latent catalyst was activated via ultrasonication leading to a cleavage of one of the two shielding NHC ligands which allowed the alkyne to coordinate to the $\mathrm{Cu}(\mathrm{I})$ center triggering thus the "click" reaction. different cell lines (MCF7 and NIH/3T3) of the complexes 1 and $\mathbf{2}$ (being devoid of the ELP sequence), 22c (bearing the ELP sequence), and fluorotris(triphenylphosphine)copper(I) (bearing no shielding NHC ligands; see the Supporting Information), as the cytotoxicity of some $\mathrm{Cu}(\mathrm{I})$ species is described in the literature. ${ }^{48,49}$ Cell toxicity tests with fluorotris(triphenylphosphine)copper(I) revealed high toxicity with $\sim 50 \%$ of the cells being alive at concentrations of $\sim 4 \mu \mathrm{mol} \mathrm{L}^{-1}$ for both cell lines (MCF7 and NIH/3T3). Already complexes 1 and 2 showed a reduced toxicity with $\sim 50 \%$ of the cells being still alive at catalyst concentrations of $75 \mu \mathrm{mol} \mathrm{L}{ }^{-1}$. Coupling of the peptide to the catalyst further decreased the cytotoxicity. Half of the cells were still alive at a concentration of $\sim 150 \mu \mathrm{mol} \mathrm{L} \mathrm{L}^{-1}$, proving an increased biocompatibility due to the shielding effect of the attached ELP chains from the $\mathrm{Cu}(\mathrm{I})$ for the cells. However, all results were similar for both cell lines (MCF7 and NIH/3T3), showing low selectivity for tumor cells.

\section{Conclusion}

In summary, we successfully synthesized and coupled ELP sequences of different chain lengths [VG, VPG, VPGVG, $(\mathrm{VPGVG})_{2}$, and (VPGVG) $)_{4}$ to the mechanophoric catalyst $\left[\mathrm{Cu}\left(\mathrm{C}_{10} \mathrm{COOH}-\mathrm{NHC}\right)_{2}\right] \mathrm{Br}$. Furthermore, a chain-extended catalyst was synthesized using the $\mathrm{N}$ - and $\mathrm{C}$-terminusdeprotected pentapeptide TFA. $\mathrm{H}_{2} \mathrm{~N}-\mathrm{VPGVG}-\mathrm{OH}$ and the two catalysts $\left[\mathrm{Cu}\left(\mathrm{C}_{10} \mathrm{COOH}-\mathrm{NHC}\right)_{2}\right] \mathrm{Br}$ and $\left[\mathrm{Cu}\left(\mathrm{C}_{3} \mathrm{NH}_{2}-\mathrm{NHC}\right)_{2} \mathrm{Br}\right.$. Secondary structure analysis via IR and $\mathrm{CD}$ spectroscopy revealed that the $\beta$-spiral forming behavior of the pentapeptide VPGVG sequence was still present after the coupling to the $\mathrm{Cu}(\mathrm{I})$ bis(NHC) complex, allowing the exploitation of the "molecular spring" behavior. The mechanoresponsive behavior was tested with ultrasonication experiments in solution using a model "click" reaction and was still present after the coupling reactions, showing an increased cleavage efficiency with an increasing chain length from $3.4 \%$ (1) to $5.6 \%$ (22e).

\section{Experimental Section}

All chemicals were obtained from commercial suppliers and were used without further purification. The mechanophoric catalysts $\left[\mathrm{Cu}\left(\mathrm{C}_{10} \mathrm{COOH}-\mathrm{NHC}\right)_{2}\right] \mathrm{Br}(\mathbf{1})$ and $\left[\mathrm{Cu}\left(\mathrm{C}_{3} \mathrm{NH}_{2}-\right.\right.$ $\mathrm{NHC})_{2} \mathrm{Br}(\mathbf{2})$ were synthesized as reported previously. ${ }^{42} \mathrm{DCM}$ and DMF were dried with calcium hydride, freshly distilled, and degassed by bubbling nitrogen for at least 20 min prior to use.

${ }^{1} \mathrm{H}$ NMR and ${ }^{13} \mathrm{C}$ NMR spectra were recorded either on a Varian Gemini 200 (400 MHz; Agilent, Germany) or on a Varian Unity Inova (500 MHz, Agilent, Germany) spectrometer. All chemical shifts $(\delta)$ are given in part per million (ppm) 
and were referred to the solvent residual signal $\left[\mathrm{CDCl}_{3}\right.$ : $7.26 \mathrm{ppm}\left({ }^{1} \mathrm{H}\right.$ NMR), $77.0 \mathrm{ppm}\left({ }^{13} \mathrm{C}\right.$ NMR $)$; DMSO- $\mathrm{d}_{6}$ : $2.50 \mathrm{ppm}\left({ }^{1} \mathrm{H}\right.$ NMR), $39.5 \mathrm{ppm}\left({ }^{13} \mathrm{C}\right.$ NMR $\left.)\right]$ and $J$ values are given in hertz $(\mathrm{Hz})$.

GPC measurements were performed on a Viscotek GPCmax VE 2001 (Malvern Panalytical Ltd., UK) using a $\mathrm{H}_{\mathrm{HR}^{-}}-\mathrm{H}$ Guard-17369 (Malvern Panalytical Ltd., UK) and a $\mathrm{GMH}_{\mathrm{HR}}-\mathrm{N}-18055$ column (Malvern Panalytical Ltd., UK) with DMF containing $10 \mathrm{mM} \mathrm{LiTf}_{2} \mathrm{~N}$ as an eluent at $60{ }^{\circ} \mathrm{C}$ and via detection of the refractive index with a Viscotek VE 3580 RI detector (Malvern Panalytical Ltd., UK) at $35{ }^{\circ} \mathrm{C}$. The external calibration was done using polystyrene standards $\left(\mathrm{MP}=1000-115,000 \mathrm{~g} \mathrm{~mol}^{-1}\right)$. The concentration of all samples was $5 \mathrm{mg} \mathrm{mL}^{-1}$ and the flow rate was $1 \mathrm{~mL} \mathrm{~min}^{-1}$.

ESI-TOF MS measurements were performed on a Bruker Daltonics microTOF (Bruker Daltonics, Germany) via direct injection with a flow rate of $180 \mu \mathrm{L} \mathrm{h}^{-1}$ using either the positive or the negative mode. Samples were prepared by dissolving the sample in a HPLC-grade solvent at a concentration of $1 \mathrm{mg} \mathrm{mL}^{-1}$ without salt addition.

Fourier-transform infrared spectroscopy was performed on a VERTEX 70 IR spectrometer (Bruker, Germany) by using a single reflex-diamond attenuated total reflectance unit for solid-state investigations. Solution experiments were performed in $\mathrm{D}_{2} \mathrm{O}$ using a Specac Omni Cell demountable cell with $\mathrm{CaF}_{2}$ windows (Sigma Aldrich, Germany) and a polytetrafluoroethylene (PTFE) spacer of $0.1 \mathrm{~mm}$. The pure solvent was measured as a background and the absorption bands are reported in $\mathrm{cm}^{-1}$.

CD spectroscopy measurements were performed on a Jasco J-810 instrument (Jasco, Germany) at $20{ }^{\circ} \mathrm{C}$ using a cuvette with a space length of $0.1 \mathrm{~mm}$ and a sample concentration of $0.4 \mathrm{mg} \mathrm{mL} \mathrm{mL}^{-1}$ in $\mathrm{D}_{2} \mathrm{O}$. Spectra were measured with a wavelength range of 250 to $195 \mathrm{~nm}$ and a scan rate of $1 \mathrm{~nm} \mathrm{~s}^{-1}$ performing 50 accumulations.

Ultrasonication experiments were conducted by placing the latent mechanocatalyst $(7.50 \mu \mathrm{mol})$ into a $10-\mathrm{mL}$ reaction vessel with two additional side necks attached to a VCX 500 ultrasonic processor (Sonics \& Materials, CT, USA) equipped with a long full-wave solid probe and an internally threaded stainless steel adapter. The vessel was evacuated and flushed with nitrogen at least three times to remove oxygen. Subsequently, benzyl azide $(750.0 \mu \mathrm{mol})$ and phenylacetylene $(750.0 \mu \mathrm{mol})$ were added as well as $10.0 \mathrm{~mL}$ of a THF- $\mathrm{d}_{8} /$ $\mathrm{MeOH}[30: 1(\mathrm{v} / \mathrm{v})]$ mixture which resulted in a catalyst concentration of $0.75 \mathrm{mM}$. To the mixture, successive cycles of pulsed ultrasound with a frequency of $20 \mathrm{kHz}$ using $20 \%$ of the maximal amplitude (experiments with $30 \%$ maximal amplitude were not successful) with a sequence of $5 \mathrm{~s}$ pulse and $10 \mathrm{~s}$ break for 90 min were applied corresponding to an ultrasound power intensity of $4.66 \mathrm{~W} \mathrm{~cm}^{-1}$ and an energy input of $11 \mathrm{~kJ}$. During this time, the mixture was cooled in a water bath to prevent the temperature from rising above $25^{\circ} \mathrm{C}$. Each cycle was followed by a waiting time of $60 \mathrm{~min}$. Samples were taken after the cycles $0,3,5,10,14$, and 17 and the conversion of the "click" reaction was checked via ${ }^{1} \mathrm{H}$ NMR spectroscopy by observing the increase in the triazole resonance at $8.11 \mathrm{ppm}$ as well as the shift of the methylene group from 4.35 to $5.59 \mathrm{ppm}$. Control experiments without ultrasound were carried out in two-necked flasks at room temperature as well as at $60{ }^{\circ} \mathrm{C}$ to prove the activation of the catalyst by ultrasound (for control experiments, see the Supporting Information).

Cytotoxicity tests were evaluated by the sulforhodamine B (SRB; Sigma Aldrich, Germany) micro culture colorimetric assay. Exponentially growing cells were seeded into 96-well plates on day 0 at the appropriate cell densities to prevent confluence of the cells during the period of the experiment. After $24 \mathrm{~h}$, the cells were treated with serial dilutions of the compounds $(0-150 \mu \mathrm{m})$ for $72 \mathrm{~h}$. After $72 \mathrm{~h}$ treatment, the supernatant medium was discarded from the 96 -well plates and the cells were fixed with $10 \%$ trichloroacetic acid. For a thorough fixation, the cells were allowed to stand at $4{ }^{\circ} \mathrm{C}$ for at least $2 \mathrm{~h}$. After fixation the cells were washed in a plate washer (Tecan Austria GmbH, Austria). The washing step was done five times with water using alternate dispensing and aspiration procedures. The plates were then stained with $100 \mu \mathrm{L}$ of $0.4 \%$ SRB in a $1 \%$ acetic acid solution for about $45 \mathrm{~min}$. After staining, the plates were washed with $1 \%$ acetic acid to remove the dye and allowed to air-dry overnight. $100 \mu \mathrm{L}$ of $10 \mathrm{mM}$ tris base solution was added to each well and the absorbance was measured at a wavelength of $570 \mathrm{~nm}$ using a plate reader (Tecan Infinite F200 Pro, Austria).

Thin-layer chromatography (TLC) was performed using Merck silica gel 60 plates (Merck, Germany). Spots on the TLC were visualized using an oxidizing agent blue stain or potassium permanganate solution or UV light (256 or $366 \mathrm{~nm})$. The blue staining solution was prepared as follows: $\left(\mathrm{NH}_{4}\right)_{6} \mathrm{Mo}_{7} \mathrm{O}_{24} \cdot 4 \mathrm{H}_{2} \mathrm{O}(1.0 \mathrm{~g})$ and $\mathrm{Ce}\left(\mathrm{SO}_{4}\right)_{2} \cdot 4 \mathrm{H}_{2} \mathrm{O}$ $(1.0 \mathrm{~g})$ were dissolved in a mixture of distilled water $(90.0 \mathrm{~mL})$ and concentrated sulfuric acid $(6.0 \mathrm{~mL})$. The potassium permanganate solution was prepared as follows: $\mathrm{KMnO}_{4}(3.0 \mathrm{~g})$ and $\mathrm{K}_{2} \mathrm{CO}_{3}(20.0 \mathrm{~g})$ were dissolved in $\mathrm{H}_{2} \mathrm{O}$ $(300 \mathrm{~mL})$ and $10 \% \mathrm{NaOH}(5.0 \mathrm{~mL})$. Column chromatography was carried out using silica gel high-purity grade, 60 Å pore size, 230-400 mesh particle size (Merck, Germany).

${ }^{1} \mathrm{H}$ and ${ }^{13} \mathrm{C}$ NMR spectra: for numbering of carbon atoms, see the Supporting Information.

\section{Procedures}

\section{Synthesis of Glycine Methyl Ester Hydrochloride (3)}

Glycine (5.0 g; 66.6 mmol, 1.0 equiv.) was dissolved in $\mathrm{MeOH}(65.0 \mathrm{~mL})$ and cooled down to $0{ }^{\circ} \mathrm{C}$ using an ice bath. $\mathrm{SOCl}_{2}$ (8.70 g; $73.3 \mathrm{mmol}, 1.1$ equiv.) was slowly added under stirring of the solution. Subsequently the reaction mixture was heated to $55^{\circ} \mathrm{C}$ for $4 \mathrm{~h}$ and then cooled down to room temperature. After stirring overnight, the solvent and the excess of $\mathrm{SOCl}_{2}$ were removed under vacuum. 
Recrystallization from $\mathrm{MeOH}$ yielded the pure product as white crystalline needles. ${ }^{50}$

White solid; yield: $6.58 \mathrm{~g}$ (79\%).

IR ( $\left.\mathrm{cm}^{-1}\right)$ : 2880 (s), 2686 (w), 2634 (w), 1742 (s), 1583 (m), 1556 (w), $1494(\mathrm{~m}), 1458$ (w), 1437 (w), $1423(\mathrm{w})$, 1400 (w), 1245 (s), $1140(\mathrm{w}), 1096(\mathrm{w}), 1058(\mathrm{~s}), 955(\mathrm{~m})$, $899(\mathrm{~s}), 878(\mathrm{~s}), 677(\mathrm{w}), 588(\mathrm{w})$.

${ }^{1} \mathrm{H}$ NMR (400 MHz, DMSO-d 6 ): $\delta=8.54(\mathrm{~s}, 3 \mathrm{H}, \mathrm{NH}), 3.77$

(s, $2 \mathrm{H}, \mathrm{H}-3), 3.73$ (s, $3 \mathrm{H}, \mathrm{H}-1)$.

${ }^{13} \mathrm{C} \mathrm{NMR}\left(100 \mathrm{MHz}, \mathrm{DMSO}-\mathrm{d}_{6}\right): \delta=167.9(\mathrm{C}-2), 52.4(\mathrm{C}-$ 1), 39.4 (C-3).

MS (ESI, $70 \mathrm{eV}): m / z[\mathrm{M}+\mathrm{H}]^{+}$calcd for $\left[\mathrm{C}_{3} \mathrm{H}_{8} \mathrm{NO}_{2}\right]^{+}$: 90.1429; found: 90.0550 .

\section{General Procedure for the $\mathrm{N}$-(tert-Butoxycarbonyl) Protection}

The corresponding amino acid (42.9 mmol; 1.0 equiv.) and $\mathrm{NaOH}$ (42.9 mmol, 1.0 equiv.) were dissolved in water (80.0 mL). Di-tert-butyl dicarbonate ( $47.2 \mathrm{mmol}$; 1.1 equiv.) was dissolved in 1,4-dioxane $(80.0 \mathrm{~mL})$ and was slowly added to the reaction mixture which was cooled via an ice bath. The mixture was left to stir for $48 \mathrm{~h}$ at room temperature and was concentrated to $\sim 50.0 \mathrm{~mL}$ afterwards. EtOAc $(150.0 \mathrm{~mL})$ was added and the $\mathrm{pH}$ was adjusted to 2 with aqueous $\mathrm{KHSO}_{4}$ (10 wt\%). The aqueous phase was extracted with EtOAc $(1 \times 150.0 \mathrm{~mL}, 6 \times 50.0 \mathrm{~mL})$ and the combined organic phases were washed with water $(20.0 \mathrm{~mL})$ afterwards. After drying over $\mathrm{Na}_{2} \mathrm{SO}_{4}$ and filtration, the solvent was removed and the product was obtained as a highly viscous and sticky oil which slowly started to crystallize in the fridge. ${ }^{51}$

\section{$N$-(tert-Butoxycarbonyl)-L-proline (4)}

White solid; yield: $8.45 \mathrm{~g}(88 \%)$.

IR (cm-1): 2968 (w), 2895 (w), 1735 (s), 1632 (s), 1478 (w), 1425 (s), $1367(\mathrm{w}), 1332(\mathrm{w}), 1253(\mathrm{w}), 1208(\mathrm{~m})$, $1187(\mathrm{w}), 1161(\mathrm{~m}), 1129(\mathrm{~m}), 1089(\mathrm{w}), 978(\mathrm{w}), 898(\mathrm{w})$, $852(\mathrm{w}), 791(\mathrm{w}), 774(\mathrm{w}), 761(\mathrm{w}), 640(\mathrm{w}), 587(\mathrm{w})$.

${ }^{1} \mathrm{H} \mathrm{NMR}\left(400 \mathrm{MHz}, \mathrm{CDCl}_{3}\right): \delta=9.57(\mathrm{~s}, 1 \mathrm{H}, \mathrm{COOH}), 4.33$ (m, $1 \mathrm{H}, \mathrm{H}-7), 3.45$ (m, $2 \mathrm{H}, \mathrm{H}-4), 2.27$ (m, $2 \mathrm{H}, \mathrm{H}-6), 1.93$ (m, $2 \mathrm{H}, \mathrm{H}-5), 1.47$ (d, $9 \mathrm{H}, \mathrm{H}-1)$.

${ }^{13} \mathrm{C}$ NMR (100 MHz, $\left.\mathrm{CDCl}_{3}\right): \delta=178.8 / 175.0(\mathrm{C}-8), 156.4$ (C-3), 154.1 (C-3), 81.5 (C-2), 80.3 (C-2), 59.2 (C-7), 58.9 (C-7), 47.0 (C-4), 46.3 (C-4), 30.8 (C-6), 28.5 (C-6), 28.4 (C-1), 24.3 (C-5), 23.6 (C-5).

MS (ESI, $70 \mathrm{eV}$ ): $\mathrm{m} / \mathrm{z}[\mathrm{M}-\mathrm{H}]^{-}$calcd for $\left[\mathrm{C}_{10} \mathrm{H}_{16} \mathrm{NO}_{4}\right]^{-}$: 214.1074; found: 214.1161.

\section{$N$-(tert-Butoxycarbonyl)-L-valine (5)}

White solid; yield: $8.12 \mathrm{~g}(88 \%)$.

IR ( $\left.\mathrm{cm}^{-1}\right)$ : 3302 (w), 2973 (w), 2937 (w), 2512 (w), 1702 (s), $1644(\mathrm{~s}), 1476(\mathrm{w}), 1456(\mathrm{w}), 1405(\mathrm{~s}), 1369(\mathrm{~m}), 1346$ (w), $1310(\mathrm{w}), 1274(\mathrm{~m}), 1254(\mathrm{w}), 1188(\mathrm{w}), 1158(\mathrm{~s}), 1125$ (w), 1094(w), 1010(w), $982(w), 959(w), 897(w), 857(w)$, $842(\mathrm{w}), 781(\mathrm{w}), 744(\mathrm{w}), 685(\mathrm{w}), 658(\mathrm{w}), 595(\mathrm{w})$. ${ }^{1} \mathrm{H}$ NMR (400 MHz, DMSO-d 6 ): $\delta=12.43(\mathrm{~s}, 1 \mathrm{H}, \mathrm{COOH})$, $6.88\left(\mathrm{~d},{ }^{3} J=8.5 \mathrm{~Hz}, 1 \mathrm{H}, \mathrm{NH}\right), 3.76(\mathrm{dd}, J=8.5,6.1 \mathrm{~Hz}, 1$ $\mathrm{H}, \mathrm{H}-3$ ), 1.97 (td, $J=13.4,6.8 \mathrm{~Hz}, 1 \mathrm{H}, \mathrm{H}-2$ ) ), 1.36 (s, $9 \mathrm{H}$, $\mathrm{H}-7), 0.85$ (t, $\left.{ }^{3} \mathrm{~J}=6.5 \mathrm{~Hz}, 6 \mathrm{H}, \mathrm{H}-1\right)$.

${ }^{13} \mathrm{C}$ NMR (100 MHz, DMSO-d $\left.\mathrm{d}_{6}\right): \delta=173.4(\mathrm{C}-4), 155.8$ (C-5), 77.9 (C-6), 59.0 (C-3), 29.4 (C-2), 28.1 (C-7), 19.1 (C-1), $18.1(\mathrm{C}-1)$.

\section{General Procedure for the Peptide Coupling}

The Boc-protected peptide (7.96 mmol; 1.0 equiv.), $\mathrm{EDC} \cdot \mathrm{HCl}$ (9.56 mmol; 1.2 equiv.), and HOBt (9.56 mmol; 1.2 equiv.) were dissolved in dry DMF $(80.0 \mathrm{~mL})$. The mixture was cooled down to $0{ }^{\circ} \mathrm{C}$ in an ice bath and was stirred for $30 \mathrm{~min}$ after the addition of DIPEA (28.67 mmol; 3.6 equiv.). Subsequently, the methyl-ester-protected peptide (7.96 mmol; 1.0 equiv.) was dissolved in $\mathrm{DMF}(40.0 \mathrm{~mL})$ and was slowly added to the solution. The reaction was stirred for further $48 \mathrm{~h}$ before the solvent was removed under reduced pressure. The residue was dissolved in EtOAc $(150.0 \mathrm{~mL})$ and water $(100.0 \mathrm{~mL})$. Afterwards the organic layer was washed with $\mathrm{HCl}(1 M, 20.0 \mathrm{~mL})$, saturated $\mathrm{NaHCO}_{3}$ solution $(20.0 \mathrm{~mL})$, and brine $(50.0 \mathrm{~mL})$. The organic layer was dried over $\mathrm{Na}_{2} \mathrm{SO}_{4}$ before it was filtrated and the solvent was removed. The crude product was either recrystallized (EtOAc-petrol ether) or purified via column chromatography (DCM-MeOH, 80:1 $\left.{ }^{\circledR} 5: 1\right) .{ }^{43}$

\section{General Procedure for the Boc Deprotection}

The Boc-protected peptide ( $4.58 \mathrm{mmol} ; 1.0$ equiv.) was dissolved in DCM $(10.0 \mathrm{~mL})$. The mixture was cooled down to $0{ }^{\circ} \mathrm{C}$ with an ice bath before TFA ( $51.75 \mathrm{mmol}$; 11.3 equiv.) was added. The mixture was stirred for $17 \mathrm{~h}$ at room temperature. Afterwards the solvent and the TFA were removed under vacuum.

\section{General Procedure for the Methyl Ester Deprotection}

The peptide ( $5.50 \mathrm{mmol} ; 1.0$ equiv.) was dissolved in THF (55.0 mL) and the mixture was cooled down to $0{ }^{\circ} \mathrm{C}$. $\mathrm{LiOH} \cdot \mathrm{H}_{2} \mathrm{O}$ (22.16 mmol; 4 equiv.) was dissolved in water $(72.0 \mathrm{~mL})$ and added to the reaction mixture. After $14 \mathrm{~h}$ of stirring at room temperature, the $\mathrm{pH}$ was adjusted to 4 by adding $1 M \mathrm{HCl}$. After extraction with EtOAc $(6 \times 50.0 \mathrm{~mL})$, the combined organic phases were dried over $\mathrm{Na}_{2} \mathrm{SO}_{4}$, filtered, and the solvent was removed.

\section{Boc-VG-OMe (6)}

White solid; yield: $16.6 \mathrm{~g}$ (72\%).

IR ( $\left.\mathrm{cm}^{-1}\right)$ : 3314 (w), 2959 (w), $1749(\mathrm{~m}), 1687$ (w), 1655

(s), 1551 (w), 1524 (s), 1438 (w), $1416(\mathrm{w}), 1386(\mathrm{w})$, 1367 (w), 1298 (w), 1246 (w), 1210 (m), 1168 (w), 1087 
(w), $1045(\mathrm{w}), 1020(\mathrm{w}), 985(\mathrm{w}), 914(\mathrm{w}), 705(\mathrm{w}), 660$ (w), $573(\mathrm{w})$.

${ }^{1} \mathrm{H} \mathrm{NMR}\left(400 \mathrm{MHz}, \mathrm{CDCl}_{3}\right): \delta=6.59(\mathrm{~s}, 1 \mathrm{H}, \mathrm{NH}), 5.08$ (d, $\left.{ }^{3} J=7.7 \mathrm{~Hz}, 1 \mathrm{H}, \mathrm{NH}\right), 4.04$ (m, 3 H, H-4 + H-8), 3.74 (s, 3 $\mathrm{H}, \mathrm{H}-10), 2.18$ (td, J = 13.4, $6.8 \mathrm{~Hz}, 1 \mathrm{H}, \mathrm{H}-5), 1.43$ (s, $9 \mathrm{H}$, $\mathrm{H}-1$ ), 0.97 (dd, $J=20.0,6.8 \mathrm{~Hz}, 6 \mathrm{H}, \mathrm{H}-6$ ).

${ }^{13} \mathrm{C} \mathrm{NMR}\left(100 \mathrm{MHz}, \mathrm{CDCl}_{3}\right): \delta=171.8(\mathrm{C}-7), 170.0(\mathrm{C}-9)$, 155.8 (C-3), 79.9 (C-2), 59.8 (C-4), 52.3 (C-10), 41.0 (C8), 30.7 (C-5), 28.2 (C-1), 19.1 (C-6), 17.5 (C-6).

MS (ESI, $70 \mathrm{eV}): \quad \mathrm{m} / z \quad[\mathrm{M}+\mathrm{Na}]^{+}$calcd for $\left[\mathrm{C}_{13} \mathrm{H}_{24} \mathrm{~N}_{2} \mathrm{O}_{5} \mathrm{Na}\right]^{+}$: 311.2485; found: 311.1577.

\section{TFA $\cdot \mathrm{H}_{2} \mathrm{~N}-\mathrm{VG}-\mathrm{OMe}(7)$}

Yellow, sticky liquid; yield: $9.32 \mathrm{~g}$ (98\%).

IR ( $\left.\mathrm{cm}^{-1}\right)$ : 2970 (w), 1744 (m), 1665 (s), 1530 (w), 1438 (w), 1369 (w), 1178 (s), 1132 (s), 1034 (w), 981 (w), 837 (m), $799(\mathrm{~m}), 721(\mathrm{~s}), 596(\mathrm{w})$.

${ }^{1} \mathrm{H}$ NMR (400 MHz, DMSO-d $\left.\mathrm{d}_{6}\right): \delta=8.87\left(\mathrm{t},{ }^{3} \mathrm{~J}=5.7 \mathrm{~Hz}, 1\right.$ $\mathrm{H}, \mathrm{NH}), 8.13\left(\mathrm{~s}, 3 \mathrm{H}, \mathrm{NH}_{3}{ }^{+}\right), 3.89$ (m, $\left.2 \mathrm{H}, \mathrm{H}-5\right), 3.63$ (m, 4 $\mathrm{H}, \mathrm{H}-3+\mathrm{H}-7), 2.07$ (m, $1 \mathrm{H}, \mathrm{H}-2) .0 .93$ (dd, ${ }^{3} \mathrm{~J}=6.9$, $3.5 \mathrm{~Hz}, 6 \mathrm{H}, \mathrm{H}-1)$.

${ }^{13} \mathrm{C}$ NMR (100 MHz, DMSO-d 6 ): $\delta=170.2(\mathrm{C}-4), 168.9$ (C-6), 57.6 (C-3), 52.2 (C-7), 41.0 (C-5), 30.2 (C-2), 18.5 (C-1), $18.0(\mathrm{C}-1)$.

MS (ESI, $70 \mathrm{eV}): m / z[\mathrm{M}]^{+}$calcd for $\left[\mathrm{C}_{8} \mathrm{H}_{17} \mathrm{~N}_{2} \mathrm{O}_{3}\right]^{+}$: 189.1234; found: 189.1242 .

\section{Boc-PG-OMe (8)}

White solid; yield: $11.72 \mathrm{~g}(52 \%)$.

IR ( $\left.\mathrm{cm}^{-1}\right)$ : 3300 (w), 2973 (w), 1753 (m), $1704(\mathrm{w}), 1685$ (m), 1660 (m), 1529 (w), 1479 (w), 1409 (s), $1364(\mathrm{~m})$, 1258 (w), 1213 (w), 1159 (s), 1124 (w), 1089 (w), 1039 (w), 1020 (w), 978 (w), $921(w), 854(w), 782(w), 755$ (w).

${ }^{1} \mathrm{H}$ NMR (400 MHz, DMSO-d 6 ): $\delta=8.22(\mathrm{~s}, 1 \mathrm{H}, \mathrm{NH}), 4.08$ (m, $1 \mathrm{H}, \mathrm{H}-7$ ), 3.81 (qd, $J=17.3,5.9 \mathrm{~Hz}, 2 \mathrm{H}, \mathrm{H}-9$ ), 3.60 (s, $3 \mathrm{H}, \mathrm{H}-11), 3.36$ ( $\mathrm{m}, 1 \mathrm{H}, \mathrm{H}-4), 3.26$ ( $\mathrm{m}, 1 \mathrm{H}, \mathrm{H}-4)$, $2.09+1.79(\mathrm{~m}, 4 \mathrm{H}, \mathrm{H}-5+\mathrm{H}-6), 1.32$ (d, $9 \mathrm{H}, \mathrm{H}-1)$.

${ }^{13} \mathrm{C}$ NMR (100 MHz, DMSO-d $\left.\mathrm{d}_{6}\right): \delta=173.5(\mathrm{C}-8), 170.6$ (C-10), 153.6 (C-3), 78.9 (C-2), 60.0 (C-7), 52.1 (C-11), 46.8 (C-4), 40.9 (C-9), 31.4 (C-6), 28.6 (C-1), 28.4 (C-1), 23.5 (C-5).

MS (ESI, $70 \mathrm{eV}): \quad m / z \quad[\mathrm{M}+\mathrm{Na}]^{+}$calcd for $\left[\mathrm{C}_{13} \mathrm{H}_{22} \mathrm{~N}_{2} \mathrm{O}_{5} \mathrm{Na}\right]^{+}$: 309.1418; found: 309.1421.

\section{$\mathrm{TFA} \cdot \mathrm{H}_{2} \mathrm{~N}-\mathrm{PG}-\mathrm{OMe}(\mathbf{9})$}

Yellow, sticky liquid; yield: $12.01 \mathrm{~g}$ (98\%).

IR ( $\left.\mathrm{cm}^{-1}\right)$ : 2959 (w), 1745 (w), 1665 (s), 1563 (m), 1413 (w), $1370(\mathrm{w}), 1175$ (s), $1126(\mathrm{~s}), 1027$ (w), $983(\mathrm{w}), 832$ (m), 798 (m), 720 (s).

${ }^{1} \mathrm{H}$ NMR (400 MHz, DMSO-d 6 ): $\delta=9.50\left(\mathrm{~s}, 1 \mathrm{H}, \mathrm{NH}_{2}{ }^{+}\right.$), $8.99\left(\mathrm{t},{ }^{3} \mathrm{~J}=5.8 \mathrm{~Hz}, 1 \mathrm{H}, \mathrm{NH},\right), 8.59\left(\mathrm{~s}, 1 \mathrm{H}, \mathrm{NH}_{2}{ }^{+}\right), 4.25$ (s, 1 H, H-4), 3.96 (m, 2 H, H-6), 3.65 (s, 3 H, H-8), 3.23 (s, 2 H, $\mathrm{H}-1$ ), 2.33 (m, $1 \mathrm{H}, \mathrm{H}-2), 1.89$ (m, $3 \mathrm{H}, \mathrm{H}-2+\mathrm{H}-3$ ).
${ }^{13} \mathrm{C}$ NMR (100 MHz, DMSO-d 6 ): $\delta=170.2(\mathrm{C}-5), 169.2$ (C-7), 59.3 (C-4), 52.4 (C-8), 46.1 (C-1), 41.2 (C-6), 29.9 (C-3), $23.8(\mathrm{C}-2)$.

MS (ESI, $70 \mathrm{eV}): \mathrm{m} / z[\mathrm{M}]^{+}$calcd for $\left[\mathrm{C}_{8} \mathrm{H}_{15} \mathrm{~N}_{2} \mathrm{O}_{3}\right]^{+}$: 187.1077; found: 187.1083 .

\section{Boc-VPG-OMe (10)}

White solid; yield: $12.70 \mathrm{~g}(81 \%) ; R_{\mathrm{f}}=0.3$ (DCM-MeOH, 20:1).

IR ( $\left.\mathrm{cm}^{-1}\right)$ : $3314(\mathrm{w}), 2971(\mathrm{w}), 1751(\mathrm{w}), 1689(\mathrm{~m}), 1629$ (w), 1509 (w), $1435(\mathrm{w}), 1390(\mathrm{w}), 1365(\mathrm{w}), 1204(\mathrm{w})$, 1163 (s), 1090 (w), 1043 (w), 1013 (w), 881 (w).

${ }^{1} \mathrm{H}$ NMR (400 MHz, DMSO-d $\left.\mathrm{d}_{6}\right): \delta=8.20\left(\mathrm{t},{ }^{3} \mathrm{~J}=5.6 \mathrm{~Hz}, 1\right.$ $\mathrm{H}, \mathrm{NH}), 6.73\left(\mathrm{~d},{ }^{3} \mathrm{~J}=8.4 \mathrm{~Hz}, 1 \mathrm{H}, \mathrm{NH}\right), 4.35$ (dd, $J=8.2$, $\left.3.7 \mathrm{~Hz}, 1 \mathrm{H}, H_{11}\right), 3.98\left(\mathrm{t},{ }^{3} \mathrm{~J}=8.2 \mathrm{~Hz}, 1 \mathrm{H}, \mathrm{H}-4\right), 3.85(\mathrm{~m}, 2$ $\mathrm{H}, \mathrm{H}-13), 3.60$ (m, $5 \mathrm{H}, \mathrm{H}-8+\mathrm{H}-15), 2.03$ (m, $1 \mathrm{H}, \mathrm{H}-5)$, 1.83 (m, 4 H, H-9 + H-10), 0.89 (dd, $J=21.9,6.6 \mathrm{~Hz}, 6 \mathrm{H}$, $\mathrm{H}-6)$.

${ }^{13} \mathrm{C}$ NMR (100 MHz, DMSO-d $\left.\mathrm{d}_{6}\right): \delta=172.6(\mathrm{C}-7), 170.8$ (C-12), 170.7 (C-14), 156.0(C-3), 78.4(C-2), $59.5(\mathrm{C}-11)$, 57.7 (C-4), 52.1 (C-15), 47.4 (C-8), 41.0 (C-13), 30.2 (C5), 29.6 (C-10), 28.6 (C-1), 24.9 (C-9), 19.6 (C-6), 18.8 (C-6).

MS (ESI, $70 \mathrm{eV}): \quad \mathrm{m} / \mathrm{z} \quad[\mathrm{M}+\mathrm{Na}]^{+}$calcd for $\left[\mathrm{C}_{18} \mathrm{H}_{31} \mathrm{~N}_{3} \mathrm{O}_{6} \mathrm{Na}\right]^{+}$: 408.2096; found: 408.2105.

\section{Boc-VPG-OH (11)}

White solid; yield: $11.81 \mathrm{~g}$ (97\%).

IR ( $\left.\mathrm{cm}^{-1}\right)$ : 3312 (w), 2972 (w), 1628 (m), $1519(\mathrm{w}), 1443$ (w), 1391 (w), 1366 (w), 1242 (w), 1161 (s), 1043 (w), $1015(\mathrm{w}), 878(\mathrm{w}), 602(\mathrm{w})$.

${ }^{1} \mathrm{H}$ NMR (400 MHz, DMSO-d ${ }_{6}$ ): $\delta=12.49(\mathrm{~s}, 1 \mathrm{H}, \mathrm{COOH})$, $8.08\left(\mathrm{t},{ }^{3} \mathrm{~J}=5.6 \mathrm{~Hz}, 1 \mathrm{H}, \mathrm{NH}\right), 6.72\left(\mathrm{~d},{ }^{3} \mathrm{~J}=8.5 \mathrm{~Hz}, 1 \mathrm{H}\right.$, $\mathrm{NH}), 4.37$ (dd, $J=8.2,3.5 \mathrm{~Hz}, 1 \mathrm{H}, \mathrm{H}-11), 3.99(\mathrm{t}$, $\left.{ }^{3} \mathrm{~J}=8.2 \mathrm{~Hz}, 1 \mathrm{H}, \mathrm{H}-4\right), 3.78$ (m, $\left.4 \mathrm{H}, \mathrm{H}-8+\mathrm{H}-13\right), 2.03$ (m, $1 \mathrm{H}, \mathrm{H}-5), 1.85$ (m, $4 \mathrm{H}, \mathrm{H}-9+\mathrm{H}-10), 0.89$ (dd, $J=22.6,6.7 \mathrm{~Hz}, 6 \mathrm{H}, \mathrm{H}-6)$.

${ }^{13} \mathrm{C}$ NMR (100 MHz, DMSO-d $\left.\mathrm{d}_{6}\right): \delta=172.3(\mathrm{C}-7), 171.6$ (C-14), 170.8 (C-12), 155.9(C-3), 78.4(C-2), 59.5 (C-11), 57.7 (C-4), 47.4 (C-8), 41.0 (C-13), 30.2 (C-5), 29.6 (C10), 28.6 (C-1), 24.9 (C-9), 19.6 (C-6), 18.8 (C-6).

MS (ESI, $70 \mathrm{eV}): m / z[\mathrm{M}-\mathrm{H}]^{-}$calcd for $\left[\mathrm{C}_{17} \mathrm{H}_{28} \mathrm{~N}_{3} \mathrm{O}_{6}\right]^{-}$: 370.2098; found: 370.1973 .

\section{TFA $\mathrm{H}_{2} \mathrm{~N}-\mathrm{VPG}-\mathrm{OMe}(\mathbf{1 2})$}

Yellow, sticky liquid; yield: $66.5 \mathrm{mg}$ (98\%).

${ }^{1} \mathrm{H} \mathrm{NMR}$ (400 MHz, DMSO-d 6 ): $\delta=8.37\left(\mathrm{t},{ }^{3} \mathrm{~J}=5.8 \mathrm{~Hz}\right.$, $1 \mathrm{H}, \mathrm{NH}), 8.06\left(\mathrm{~s}, 3 \mathrm{H}, \mathrm{NH}_{3}{ }^{+}\right), 4.42(\mathrm{dd}, J=8.4,5.1 \mathrm{~Hz}, 1$ $\mathrm{H}, \mathrm{H}-8$ ), 3.97 (m, $1 \mathrm{H}, \mathrm{H}-3$ ), 3.87 (m, $2 \mathrm{H}, \mathrm{H}-10$ ), 3.60 $(\mathrm{m}, 5 \mathrm{H}, \mathrm{H}-5+\mathrm{H}-12), 2.11(\mathrm{~m}, 2 \mathrm{H}, \mathrm{H}-2+\mathrm{H}-7), 1.81$ (m, $3 \mathrm{H}, \mathrm{H}-6+\mathrm{H}-7), 0.99$ (dd, $J=31.8,6.9 \mathrm{~Hz}$, $6 \mathrm{H}, \mathrm{H}-1)$.

${ }^{13} \mathrm{C}$ NMR (100 MHz, DMSO-d 6 ): $\delta=172.0(\mathrm{C}-4), 170.6$ (C-9), 167.2 (C-11), 59.8 (C-8), 56.2 (C-3), 52.1 (C-12), 
47.8 (C-5), 40.9 (C-10), 27.9 (C-2), 29.7 (C-7), 25.0 (C-6), 18.9 (C-1), 17.5 (C-1).

\section{Boc-VPGVG-OMe (13)}

White solid; yield: $12.65 \mathrm{~g}(73 \%) ; R_{\mathrm{f}}=0.16$ (DCM-MeOH, 20:1).

IR ( $\left.\mathrm{cm}^{-1}\right)$ : $3311(\mathrm{w}), 2966$ (w), $1746(\mathrm{w}), 1626$ (s), 1522 (m), 1439 (w), 1390 (w), 1366 (w), 1311 (w), 1207 (w), 1162 (s), 1039 (w), 1013 (w), 675 (w), 563 (w).

${ }^{1} \mathrm{H}$ NMR (400 MHz, DMSO-d $\mathrm{d}_{6}$ ): $\delta=8.38\left(\mathrm{t},{ }^{3} \mathrm{~J}=5.8 \mathrm{~Hz}, 1\right.$ $\mathrm{H}, \mathrm{NH}), 8.21\left(\mathrm{t},{ }^{3} \mathrm{~J}=5.5 \mathrm{~Hz}, 1 \mathrm{H}, \mathrm{NH}\right), 7.58\left(\mathrm{~d},{ }^{3} \mathrm{~J}=8.9 \mathrm{~Hz}\right.$, $1 \mathrm{H}, \mathrm{NH}), 6.72\left(\mathrm{~d},{ }^{3} \mathrm{~J}=8.3 \mathrm{~Hz}, 1 \mathrm{H}, \mathrm{NH}\right), 4.29(\mathrm{dd}, J=7.5$, $5.0 \mathrm{~Hz}, 1 \mathrm{H}, \mathrm{H}-4), 4.15$ (dd, $J=8.7,7.3 \mathrm{~Hz}, 1 \mathrm{H}, \mathrm{H}-11$ ), $3.96\left(\mathrm{t},{ }^{3} \mathrm{~J}=8.3 \mathrm{~Hz}, 1 \mathrm{H}, \mathrm{H}-15\right), 3.82$ (m, $\left.2 \mathrm{H}, \mathrm{H}-19\right), 3.71$ (m, $3 \mathrm{H}, \mathrm{H}-8+\mathrm{H}-13), 3.60$ (m, $4 \mathrm{H}, \mathrm{H}-8+\mathrm{H}-21), 1.92$ (m, 6 H, H-5 + H-9 + H-10 + H-16), 1.35 (s, 9 H, H-1), 0.86 (m, $12 \mathrm{H}, \mathrm{H}-6+\mathrm{H}-17)$.

${ }^{13} \mathrm{C}$ NMR (100 MHz, DMSO-d 6 ): $\delta=172.5(\mathrm{C}-7), 171.8$ (C-18), 171.0 (C-12), 170.6 (C-20), 169.1 (C-14), 156.0 (C-3), 78.4 (C-2), 60.1 (C-15), 58.1 (C-11), 57.8 (C-4), 52.1 (C-21), 47.6 (C-8), 42.6 (C-13), 41.0 (C-19), 30.9 (C16), 30.2 (C-5), 29.6 (C-10), 28.6 (C-1), 25.0 (C-9), 19.5 (C-17), 19.5 (C-6), 18.9 (C-6), 18.6 (C-17).

MS (ESI, $70 \mathrm{eV}): \mathrm{m} / \mathrm{z} \quad[\mathrm{M}+\mathrm{Na}]^{+}$calcd for $\left[\mathrm{C}_{25} \mathrm{H}_{43} \mathrm{~N}_{5} \mathrm{O}_{8} \mathrm{Na}\right]^{+}$: 564.3014; found: 564.3004 .

\section{TFA. ${ }_{2} \mathrm{~N}-V P G V G-O M e(14)$}

Yellow solid; yield: $2.45 \mathrm{~g}(96 \%)$.

IR ( $\left.\mathrm{cm}^{-1}\right)$ : 3290 (w), 2967 (w), 1748 (w), 1644 (s), 1524 (m), $1454(\mathrm{w}), 1731$ (w), $1199(\mathrm{~s}), 1176(\mathrm{~s}), 1132(\mathrm{~s}), 1036$ (w), $835(w), 800(w), 720(w), 599(w)$.

${ }^{1} \mathrm{H}$ NMR (400 MHz, DMSO-d $\left.\mathrm{d}_{6}\right): \delta=8.42\left(\mathrm{t},{ }^{3} \mathrm{~J}=5.9 \mathrm{~Hz}, 1\right.$ $\mathrm{H}, \mathrm{NH}), 8.20\left(\mathrm{t},{ }^{3} \mathrm{~J}=5.7 \mathrm{~Hz}, 1 \mathrm{H}, \mathrm{NH}\right), 8.01\left(\mathrm{~s}, 3 \mathrm{H}, \mathrm{NH}_{3}{ }^{+}\right)$, $7.67\left(\mathrm{dd},{ }^{3} \mathrm{~J}=8.8 \mathrm{~Hz}, 1 \mathrm{H}, \mathrm{NH}\right), 4.42(\mathrm{dd}, J=8.3,5.3 \mathrm{~Hz}, 1 \mathrm{H}$, $\mathrm{H}-3$ ), 4.18 (dd, $J=8.8,6.7 \mathrm{~Hz}, 1 \mathrm{H}, \mathrm{H}-8), 3.95$ (m, $1 \mathrm{H}, \mathrm{H}-$ 12), 3.83 ( $\mathrm{m}, 2 \mathrm{H}, \mathrm{H}-16), 3.70(\mathrm{~m}, 3 \mathrm{H}, \mathrm{H}-5+\mathrm{H}-10) 3.60(\mathrm{~s}$, $3 \mathrm{H}, \mathrm{H}-18), 3.50$ ( $\mathrm{m}, 1 \mathrm{H}, \mathrm{H}-5), 2.09-1.82(\mathrm{~m}, 6 \mathrm{H}, \mathrm{H}-2+\mathrm{H}-$ $6+\mathrm{H}-7+\mathrm{H}-13), 0.87(\mathrm{~m}, 12 \mathrm{H}, \mathrm{H}-1+\mathrm{H}-14)$.

${ }^{13} \mathrm{C}$ NMR (100 MHz, DMSO-d 6 ): $\delta=171.8(\mathrm{C}-4+\mathrm{C}-15)$, 170.6 (C-9), 169.0 (C-11), 167.3 (C-17), $60.0(\mathrm{C}-12), 57.8$ (C-8), 56.2 (C-3), 52.1 (C-18), 47.9 (C-5), 42.4 (C-10), 40.9 (C-16), 31.1 (C-13), 29.7 (C-2 + C-7), 25.0 (C-6), 19.5 (C-14), 18.9 (C-14), 18.4 (C-1), $17.6(\mathrm{C}-1)$.

MS (ESI, $70 \mathrm{eV}$ ): $\mathrm{m} / \mathrm{z}[\mathrm{M}]^{+}$calcd for $\left[\mathrm{C}_{20} \mathrm{H}_{36} \mathrm{~N}_{5} \mathrm{O}_{6}\right]^{+}$: 442.2660; found: 442.2680 .

\section{Boc-VPGVG-OH (15)}

White solid; yield: $2.83 \mathrm{~g}$ (98\%).

IR ( $\left.\mathrm{cm}^{-1}\right)$ : 3298 (w), 2968 (w), 1627 (s), 1521 (m), 1447 (w), $1391(\mathrm{w}), 1367(\mathrm{w}), 1162(\mathrm{~m}), 1015(\mathrm{w}), 878(\mathrm{w}), 677$ (w), $620(\mathrm{w})$.

${ }^{1} \mathrm{H}$ NMR (400 MHz, DMSO-d ${ }_{6}$ ): $\delta=12.48(\mathrm{~s}, 1 \mathrm{H}, \mathrm{COOH})$, $8.27\left(\mathrm{t},{ }^{3} \mathrm{~J}=5.9 \mathrm{~Hz}, 1 \mathrm{H}, \mathrm{NH}\right), 8.21\left(\mathrm{t},{ }^{3} \mathrm{~J}=5.6 \mathrm{~Hz}, 1 \mathrm{H}\right.$, $\mathrm{NH}), 7.59\left(\mathrm{~d},{ }^{3} \mathrm{~J}=9.0 \mathrm{~Hz}, 1 \mathrm{H}, \mathrm{NH}\right), 6.71\left(\mathrm{~d},{ }^{3} \mathrm{~J}=8.4 \mathrm{~Hz}, 1\right.$
$\mathrm{H}, \mathrm{NH}$ ), 4.30 (dd, $J=7.5,5.3 \mathrm{~Hz}, 1 \mathrm{H}, \mathrm{H}-4$ ), 4.16 (dd, $J=8.8,7.2 \mathrm{~Hz}, 1 \mathrm{H}, \mathrm{H}-11), 3.96\left(\mathrm{t},{ }^{3} \mathrm{~J}=8.3 \mathrm{~Hz}, 1 \mathrm{H}, \mathrm{H}-\right.$ 15), 3.73 (m, 5 H, H-8 + H-13 + H-19), 3.56 (m, $1 \mathrm{H}, \mathrm{H}-$ 8), 1.94 (m, $6 \mathrm{H}, \mathrm{H}-5+\mathrm{H}-9+\mathrm{H}-10+\mathrm{H}-16), 1.35$ (s, 9 $\mathrm{H}, \mathrm{H}-1), 0.85$ (m, $12 \mathrm{H}, \mathrm{H}-6+\mathrm{H}-17)$.

${ }^{13} \mathrm{C}$ NMR (100 MHz, DMSO-d $\left.\mathrm{d}_{6}\right): \delta=172.4(\mathrm{C}-7), 171.6$ (C-18 + C-20), 171.0 (C-12), 169.1 (C-14), 156.0 (C-3), 78.4 (C-2), 60.1 (C-15), 58.1 (C-11), 57.8 (C-4), 47.6 (C8), 42.6 (C-13), 41.0 (C-19), 31.0 (C-16), 30.2 (C-5), 29.6 (C-10), 28.6 (C-1), 25.0 (C-9), 19.6 (C-17), 19.5 (C-6), 18.9 (C-6), 18.6 (C-17).

MS (ESI, $70 \mathrm{eV}): \mathrm{m} / z[\mathrm{M}-\mathrm{H}]^{-}$calcd for $\left[\mathrm{C}_{24} \mathrm{H}_{40} \mathrm{~N}_{5} \mathrm{O}_{8}\right]^{-}$: 526.2871; found: 526.2959.

\section{TFA $\cdot \mathrm{H}_{2} \mathrm{~N}-\mathrm{VPGVG}-\mathrm{OH}(\mathbf{1 6})$}

White solid; yield: $154 \mathrm{mg}$ (98\%).

IR ( $\left.\mathrm{cm}^{-1}\right)$ : 2969 (w), 1642 (s), 1523 (m), 1372 (w), 1179 (s), $1133(\mathrm{~s}), 1034(\mathrm{w}), 835(\mathrm{w}), 799(\mathrm{w}), 720(\mathrm{w}), 599(\mathrm{w})$. ${ }^{1} \mathrm{H} \mathrm{NMR}\left(400 \mathrm{MHz}, \mathrm{DMSO}-\mathrm{d}_{6}\right): \delta=12.43(\mathrm{~s}, 1 \mathrm{H}, \mathrm{COOH})$, $8.31\left(\mathrm{t},{ }^{3} \mathrm{~J}=6.0 \mathrm{~Hz}, 1 \mathrm{H}, \mathrm{NH}\right), 8.20\left(\mathrm{t},{ }^{3} \mathrm{~J}=5.7 \mathrm{~Hz}, 1 \mathrm{H}\right.$, $\mathrm{NH}), 8.03\left(\mathrm{~s}, 3 \mathrm{H}, \mathrm{NH}_{3}{ }^{+}\right), 7.67\left(\mathrm{~d},{ }^{3} \mathrm{~J}=8.9 \mathrm{~Hz}, 1 \mathrm{H}, \mathrm{NH}\right.$ ), 4.41 (dd, $J=8.2,5.2 \mathrm{~Hz}, 1 \mathrm{H}, \mathrm{H}-3$ ), 4.18 (dd, $J=10.4$, $5.0 \mathrm{~Hz}, 1 \mathrm{H}, \mathrm{H}-8$, ), 3.95 (m, $1 \mathrm{H}, \mathrm{H}-12), 3.70$ (m, $5 \mathrm{H}, \mathrm{H}-$ $5+\mathrm{H}-10+\mathrm{H}-16), 3.50$ (m, $1 \mathrm{H}, \mathrm{H}-5), 2.09$ (m, $2 \mathrm{H}, \mathrm{H}-$ $2+\mathrm{H}-13), 1.95$ (m, $2 \mathrm{H}, \mathrm{H}-6+\mathrm{H}-7), 1.82$ (m, $2 \mathrm{H}, \mathrm{H}-$ $6+\mathrm{H}-7), 0.92(\mathrm{~m}, 12 \mathrm{H}, \mathrm{H}-1+\mathrm{H}-14)$.

${ }^{13} \mathrm{C}$ NMR $(100 \mathrm{MHz}$, DMSO-d 6 ): $\delta=171.8(\mathrm{C}-4), 171.6(\mathrm{C}-$ 17), 171.5 (C-15), $171.0(\mathrm{C}-12), 168.9$ (C-11), 167.3 (C-9), $60.0(\mathrm{C}-12), 57.8(\mathrm{C}-8), 56.2(\mathrm{C}-3), 47.8(\mathrm{C}-5), 42.4(\mathrm{C}-10)$, 41.0(C-16), 31.1 (C-13), 29.8 (C-7), $29.7(\mathrm{C}-2), 25.0(\mathrm{C}-6)$, 19.6 (C-14), 18.9 (C-14), 18.4 (C-1), 17.6 (C-1).

MS (ESI, $70 \mathrm{eV}): \mathrm{m} / z[\mathrm{M}-\mathrm{H}]^{-}$calcd for $\left[\mathrm{C}_{19} \mathrm{H}_{32} \mathrm{~N}_{5} \mathrm{O}_{6}\right]^{-}$: 426.2347; found: 426.2336 .

\section{Boc-(VPGVG) $)_{2}-\mathrm{OMe}$ (17)}

White solid; yield: $2.67 \mathrm{~g}(70 \%) ; R_{\mathrm{f}}=0.12(\mathrm{DCM}-\mathrm{MeOH}$, 10:1).

IR ( $\left.\mathrm{cm}^{-1}\right)$ : 3300 (w), $2965(\mathrm{w}), 1626$ (s), $1518(\mathrm{~m}), 1440$ (w), 1390 (w), $1367(\mathrm{w}), 1206(\mathrm{w}), 1164(\mathrm{~m}), 1012(\mathrm{w})$, $879(\mathrm{w}), 665(\mathrm{w}), 614(\mathrm{w})$.

${ }^{1} \mathrm{H}$ NMR (400 MHz, DMSO-d $\left.\mathrm{d}_{6}\right): \delta=8.39\left(\mathrm{t},{ }^{3} \mathrm{~J}=5.9 \mathrm{~Hz}, 1\right.$ $\mathrm{H}, \mathrm{NH}), 8.26\left(\mathrm{t},{ }^{3} \mathrm{~J}=5.8 \mathrm{~Hz}, 1 \mathrm{H}, \mathrm{NH}\right), 8.20\left(\mathrm{t},{ }^{3} \mathrm{~J}=5.7 \mathrm{~Hz}\right.$, $1 \mathrm{H}, \mathrm{NH}), 8.16\left(\mathrm{t},{ }^{3} \mathrm{~J}=5.8 \mathrm{~Hz}, 1 \mathrm{H}, \mathrm{NH}\right), 7.90(\mathrm{~d}$, $\left.{ }^{3} J=8.5 \mathrm{~Hz}, 1 \mathrm{H}, \mathrm{NH}\right), 7.62\left(\mathrm{~d},{ }^{3} \mathrm{~J}=8.9 \mathrm{~Hz}, 2 \mathrm{H}, \mathrm{NH}\right)$, $6.78\left(\mathrm{~d},{ }^{3} \mathrm{~J}=8.4 \mathrm{~Hz}, 1 \mathrm{H}, \mathrm{NH}\right), 4.27$ (m, 3 H, H-4 + H-15), 4.16 ( $\mathrm{m}, 2 \mathrm{H}, \mathrm{H}-11), 3.97\left(\mathrm{t},{ }^{3} \mathrm{~J}=8.4 \mathrm{~Hz}, 1 \mathrm{H}, \mathrm{H}-4\right), 3.73$ (m, $10 \mathrm{H}, \mathrm{H}-8+\mathrm{H}-13+\mathrm{H}-19), 3.60(\mathrm{~m}, 5 \mathrm{H}, \mathrm{H}-8+\mathrm{H}-$ 21), 1.92 (m, $12 \mathrm{H}, \mathrm{H}-5+\mathrm{H}-9+\mathrm{H}-10+\mathrm{H}-16), 1.35$ (s, $9 \mathrm{H}, \mathrm{H}-1), 0.87$ (m, $24 \mathrm{H}, \mathrm{H}-6+\mathrm{H}-17)$.

${ }^{13} \mathrm{CNMR}\left(100 \mathrm{MHz}, \mathrm{DMSO}-\mathrm{d}_{6}\right): \delta=171.9(\mathrm{C}-7), 171.9(\mathrm{C}-$ 7), 171.3 (C-18), 170.9 (C-18), 170.8 (C-12), 170.1 (C-20), 169.8 (C-12), 168.6 (C-20), 168.6 (C-14), $168.6(\mathrm{C}-14)$, 155.5 (C-3), 78.0 (C-2), 59.7 (C-15), 59.5 (C-15), $58.3(\mathrm{C}-$ 11), 57.5 (C-11), 57.4 (C-4), $55.6(\mathrm{C}-4), 51.6(\mathrm{C}-21), 47.3$ 
(C-8), 47.2 (C-8), 42.1 (C-13), 42.0 (C-13), 41.6 (C-19), 40.5 (C-19), 30.5 (C-16), 30.4 (C-16), 30.1 (C-5), 29.7 (C5), 29.2(C-10), 29.1 (C-10), 28.2(C-1), 24.6(C-9), 24.4(C9), 19.1 (C-17), 19.0 (C-6 + C-17), $19.0(\mathrm{C}-6), 18.5(\mathrm{C}-17)$, 18.4 (C-6), 18.3 (C-17), 18.0 (C-6).

MS (ESI, $70 \mathrm{eV}): \quad \mathrm{m} / z \quad[\mathrm{M}+\mathrm{Na}]^{+}$calcd for $\left[\mathrm{C}_{44} \mathrm{H}_{74} \mathrm{~N}_{10} \mathrm{O}_{13} \mathrm{Na}\right]^{+}$: 973.5329; found: 973.5324 .

\section{$\mathrm{TFA} \cdot \mathrm{H}_{2} \mathrm{~N}-(\mathrm{VPGVG})_{2}-\mathrm{OMe}$ (18)}

Yellow solid; yield: $860 \mathrm{mg}$ (98\%).

IR (cm-1): 3299 (w), 2965 (w), 1749 (w), 1641 (s), 1522 (m), 1448 (w), 1200 (m), 1173 (m), $1034(\mathrm{w}), 835$ (w), $719(\mathrm{w}), 701(\mathrm{w}), 602(\mathrm{w})$.

${ }^{1} \mathrm{H}$ NMR (400 MHz, DMSO-d $\left.\mathrm{d}_{6}\right): \delta=8.42\left(\mathrm{t},{ }^{3} \mathrm{~J}=5.9 \mathrm{~Hz}, 1\right.$ $\mathrm{H}, \mathrm{NH}$ ), 8.20 (dd, $J=12.3 \mathrm{~Hz}, 5.9 \mathrm{~Hz}, 2 \mathrm{H}, \mathrm{NH}), 8.16$ (t, $\left.{ }^{3} J=5.8 \mathrm{~Hz}, 1 \mathrm{H}, \mathrm{NH}\right), 8.02\left(\mathrm{~s}, 3 \mathrm{H}, \mathrm{NH}_{3}{ }^{+}\right), 7.89$ (d, $\left.{ }^{3} J=8.6 \mathrm{~Hz}, 1 \mathrm{H}, \mathrm{NH}\right), 7.69\left(\mathrm{~d},{ }^{3} J=8.7 \mathrm{~Hz}, 1 \mathrm{H}, \mathrm{NH}\right), 7.62$ $\left(\mathrm{d},{ }^{3} \mathrm{~J}=8.9 \mathrm{~Hz}, 1 \mathrm{H}, \mathrm{NH}\right), 4.43(\mathrm{dd}, J=8.3,5.3 \mathrm{~Hz}, 1 \mathrm{H}, \mathrm{H}-$ 3), 4.32 (m, $2 \mathrm{H}, \mathrm{H}-8), 4.18$ (m, $2 \mathrm{H}, \mathrm{H}-12), 3.97(\mathrm{~m}, 1 \mathrm{H}$, $\mathrm{H}-3), 3.73$ (m, $10 \mathrm{H}, \mathrm{H}-5+\mathrm{H}-10+\mathrm{H}-16), 3.62(\mathrm{~s}, 3 \mathrm{H}$, $\mathrm{H}-18$ ), 3.49 (m, $2 \mathrm{H}, \mathrm{H}-5), 2.13-1.79$ ( $\mathrm{m}, 12 \mathrm{H}, \mathrm{H}-2+\mathrm{H}-$ $6+\mathrm{H}-7+\mathrm{H}-13), 0.87$ (m, $24 \mathrm{H}, \mathrm{H}-1+\mathrm{H}-14)$.

${ }^{13} \mathrm{C}$ NMR (100 MHz, DMSO-d $\left.\mathrm{d}_{6}\right): \delta=172.3(\mathrm{C}-4), 171.8$ (C-4 + C-15), 171.5 (C-15), 170.6 (C-9), 170.3 (C-9), 169.1 (C-11), 169.0 (C-11), 168.9 (C-17), 167.3 (C-17), 60.0 (C-12), 59.9 (C-12), 58.1 (C-8), 57.9 (C-8), 56.2 (C3), 56.1 (C-3), 52.1 (C-18), 47.9 (C-5), 47.6 (C-5), 42.5 (C-10), 42.4 (C-10), 42.0 (C-16), $41.0(\mathrm{C}-16), 31.0(\mathrm{C}-13)$, 31.0 (C-13), 30.6 (C-2), 29.8 (C-2), 29.7 (C-7), 29.7 (C-7), 25.1 (C-6), 24.9 (C-6), 19.6 (C-14), 19.5 (C-1), 18.9 (C14), 18.5 (C-1), 18.5 (C-14), $17.6(\mathrm{C}-1)$.

MS (ESI, $70 \mathrm{eV}): \mathrm{m} / z[\mathrm{M}]^{+}$calcd for $\left[\mathrm{C}_{39} \mathrm{H}_{67} \mathrm{~N}_{10} \mathrm{O}_{11}\right]^{+}$: 851.4975; found: 851.4985 .

\section{Boc-(VPGVG) $2-\mathrm{OH}$ (19)}

White solid; yield: $849 \mathrm{mg}$ (91\%).

IR ( $\left.\mathrm{cm}^{-1}\right)$ : 3287 (w), 2965 (w), 1622 (s), 1523 (m), 1444 (w), $1390(\mathrm{w}), 1367(\mathrm{w}), 1236(\mathrm{w}), 1165(\mathrm{~m}), 1042(\mathrm{w})$, $880(\mathrm{w}), 660(\mathrm{w}), 618(\mathrm{w})$.

${ }^{1} \mathrm{H}$ NMR (400 MHz, DMSO-d $\left.\mathrm{d}_{6}\right): \delta=12.47(\mathrm{~s}, 1 \mathrm{H}, \mathrm{COOH})$, 8.27 (dd, $J=11.2,5.6 \mathrm{~Hz}, 2 \mathrm{H}, \mathrm{NH}), 8.20\left(\mathrm{t},{ }^{3} \mathrm{~J}=5.7 \mathrm{~Hz}, 1\right.$ $\mathrm{H}, \mathrm{NH}), 8.16\left(\mathrm{t},{ }^{3} \mathrm{~J}=5.8 \mathrm{~Hz}, 1 \mathrm{H}, \mathrm{NH}\right), 7.92\left(\mathrm{~d},{ }^{3} \mathrm{~J}=8.5 \mathrm{~Hz}\right.$, $1 \mathrm{H}, \mathrm{NH}), 7.61\left(\mathrm{t},{ }^{3} \mathrm{~J}=9.4 \mathrm{~Hz}, 2 \mathrm{H}, \mathrm{NH}\right), 6.80$ (d, $\left.{ }^{3} J=8.5 \mathrm{~Hz}, 1 \mathrm{H}, \mathrm{NH}\right), 4.29(\mathrm{~m}, 3 \mathrm{H}, \mathrm{H}-4+\mathrm{H}-11), 4.17$ $(\mathrm{dd}, J=8.9,6.9 \mathrm{~Hz}, 1 \mathrm{H}, \mathrm{H}-11), 4.10(\mathrm{dd}, J=8.6,7.8 \mathrm{~Hz}, 1$ $\mathrm{H}, \mathrm{H}-15), 3.97$ (t, $\left.{ }^{3} \mathrm{~J}=8.3 \mathrm{~Hz}, 1 \mathrm{H}, \mathrm{H}-15\right), 3.73(\mathrm{~m}, 10 \mathrm{H}$, $\mathrm{H}-8+\mathrm{H}-13+\mathrm{H}-19), 3.56(\mathrm{~m}, 2 \mathrm{H}, \mathrm{H}-8), 1.94(\mathrm{~m}, 12 \mathrm{H}$, $\mathrm{H}-5+\mathrm{H}-9+\mathrm{H}-10+\mathrm{H}-16), 1.35$ (s, $9 \mathrm{H}, \mathrm{H}-1), 0.83$ (m, $24 \mathrm{H}, \mathrm{H}-6+\mathrm{H}-17)$.

${ }^{13} \mathrm{C}$ NMR (100 MHz, DMSO-d 6 ): $\delta=172.0(\mathrm{C}-7), 171.9$ (C-7), $171.1(\mathrm{C}-18), 171.1(\mathrm{C}-12), 171.0(\mathrm{C}-18), 170.8$ (C12), 169.8 (C-20), 168.6 (C-14), $168.6(\mathrm{C}-20), 155.5(\mathrm{C}-$ 3), 78.0 (C-2), 59.7 (C-15), 59.5 (C-15), 58.3 (C-11), 57.5 (C-11), 57.4(C-4), 55.6(C-4), 47.2(C-8), $47.2(\mathrm{C}-8), 42.1$
(C-13), 42.0 (C-13), 41.6 (C-19), $40.6(\mathrm{C}-19), 30.6(\mathrm{C}-16)$, 30.5 (C-16), 30.1 (C-5), 29.8 (C-5), 29.2 (C-10), 29.1 (C10), 28.2 (C-1), 24.6 (C-9), 24.4 (C-9), 19.1 (C-17), 19.1 (C-17), 19.0 (C-6), 18.4 (C-17), 18.3 (C-6), 18.0 (C-6). MS (ESI, $70 \mathrm{eV}$ ): $m / z[\mathrm{M}-\mathrm{H}]^{-}$calcd for $\left[\mathrm{C}_{43} \mathrm{H}_{71} \mathrm{~N}_{10} \mathrm{O}_{13}\right]^{-}$: 935.5197; found: 935.5189 .

\section{Boc-(VPGVG) $)_{4}-\mathrm{OMe}$ (20)}

Slightly yellow solid; yield: $704 \mathrm{mg}(44 \%), R_{\mathrm{f}}=0.29$ (DCM-MeOH, 5:1).

IR ( $\left.\mathrm{cm}^{-1}\right)$ : 3298 (w), 2967 (w), 1627 (s), $1523(\mathrm{~m}), 1443$ (w), 1391 (w), $1369(\mathrm{w}), 1202$ (w), $1172(\mathrm{~m}), 1132(\mathrm{w})$, 10126(w), $719(\mathrm{w})$.

${ }^{1} \mathrm{H}$ NMR (400 MHz, DMSO-d $\left.\mathrm{d}_{6}\right): \delta=8.39\left(\mathrm{t},{ }^{3} \mathrm{~J}=5.9 \mathrm{~Hz}, 1\right.$ $\mathrm{H}, \mathrm{NH}), 8.20(\mathrm{~m}, 7 \mathrm{H}, \mathrm{NH}), 7.92(\mathrm{~m}, 3 \mathrm{H}, \mathrm{NH}), 7.62$ (d, $\left.{ }^{3} \mathrm{~J}=8.8 \mathrm{~Hz}, 4 \mathrm{H}, \mathrm{NH}\right), 6.79\left(\mathrm{~d},{ }^{3} \mathrm{~J}=8.4 \mathrm{~Hz}, 1 \mathrm{H}, \mathrm{NH}\right), 4.28$ (m, $7 \mathrm{H}, \mathrm{H}-4+\mathrm{H}-15), 4.15(\mathrm{~m}, 4 \mathrm{H}, \mathrm{H}-11), 3.97$ (t, $\left.{ }^{3} \mathrm{~J}=8.4 \mathrm{~Hz}, 1 \mathrm{H}, \mathrm{H}-4\right), 3.72(\mathrm{~m}, 20 \mathrm{H}, \mathrm{H}-8+\mathrm{H}-13+\mathrm{H}$, $3.60(\mathrm{~m}, 7 \mathrm{H}, \mathrm{H}-8+\mathrm{H}-21), 1.92(\mathrm{~m}, 24 \mathrm{H}, \mathrm{H}-5+\mathrm{H}-$ $9+\mathrm{H}-10+\mathrm{H}-16), 1.35$ (s, $9 \mathrm{H}, \mathrm{H}-1), 0.87$ (m, $48 \mathrm{H}, \mathrm{H}-$ $6+\mathrm{H}-17)$.

MS (ESI, $70 \mathrm{eV}): \quad m / z \quad[\mathrm{M}+\mathrm{Na}]^{+}$calcd for $\left[\mathrm{C}_{82} \mathrm{H}_{136} \mathrm{~N}_{20} \mathrm{O}_{23} \mathrm{Na}\right]^{+}$: 1791.9979; found: 1791.9966 .

\section{$\mathrm{TFA} \cdot \mathrm{H}_{2} \mathrm{~N}-(\mathrm{VPGVG})_{4}-\mathrm{OMe}$ (21)}

Yellow solid; yield: $702 \mathrm{mg}$ (99\%).

IR ( $\left.\mathrm{cm}^{-1}\right)$ : $3287(\mathrm{w}), 2965$ (w), 1627 (s), 1525 (m), 1448 (w), $1200(w), 1177(w), 1131(w), 719(w)$.

${ }^{1} \mathrm{H} \mathrm{NMR}\left(400 \mathrm{MHz}\right.$, DMSO-d $\left.\mathrm{d}_{6}\right): \delta=8.40\left(\mathrm{t},{ }^{3} \mathrm{~J}=5.8 \mathrm{~Hz}, 1\right.$ $\mathrm{H}, \mathrm{NH}), 8.19(\mathrm{~m}, 7 \mathrm{H}, \mathrm{NH}), 8.03\left(\mathrm{~m}, 3 \mathrm{H}^{-\mathrm{NH}_{3}}{ }^{+}\right), 7.91(\mathrm{~m}, 3$ $\mathrm{H}, \mathrm{NH}), 7.61\left(\mathrm{~d},{ }^{3} \mathrm{~J}=8.8 \mathrm{~Hz}, 4 \mathrm{H}, \mathrm{NH}\right), 4.42(\mathrm{dd}, J=8.2$, $5.3 \mathrm{~Hz}, 1 \mathrm{H}, \mathrm{H}-3), 4.31(\mathrm{~m}, 6 \mathrm{H}, \mathrm{H}-3+\mathrm{H}-8), 4.15(\mathrm{~m}, 4 \mathrm{H}$, $\mathrm{H}-12), 3.96$ (m, $1 \mathrm{H}, \mathrm{H}-3), 3.72$ (m, $20 \mathrm{H}, \mathrm{H}-5+\mathrm{H}-$ $10+\mathrm{H}-16), 3.60$ (m, $7 \mathrm{H}, \mathrm{H}-5+\mathrm{H}-18), 1.94$ (m, $24 \mathrm{H}$, $\mathrm{H}-2+\mathrm{H}-6+\mathrm{H}-7+\mathrm{H}-13), 0.83(\mathrm{~m}, 48 \mathrm{H}, \mathrm{H}-1+\mathrm{H}-$ 14).

MS (ESI, $70 \mathrm{eV}$ ): $m / z[\mathrm{M}]^{+}$calcd for $\left[\mathrm{C}_{77} \mathrm{H}_{129} \mathrm{~N}_{20} \mathrm{O}_{21}\right]^{+}$: 1669.9636; found: 1669.9434 .

\section{General Procedure for the Peptide Coupling to [Cu $\left.\left(\mathrm{C}_{10} \mathrm{COOH}-\mathrm{NHC}\right)_{2}\right] \mathrm{Br}$}

$\left[\mathrm{Cu}\left(\mathrm{C}_{10} \mathrm{COOH}-\mathrm{NHC}\right)_{2}\right] \mathrm{Br}(65 \mu \mathrm{mol} ; 1.0$ equiv.) was dissolved in DMF $(500 \mu \mathrm{L})$. The mixture was cooled down to $0{ }^{\circ} \mathrm{C}$ in an ice bath and a molecular sieve ( $3 \AA$ ) and DCC ( $0.143 \mathrm{mmol} ; 2.2$ equiv.) were added. The mixture was stirred for $10 \mathrm{~min}$ before pentafluorophenol $(0.143 \mathrm{mmol}$; 2.2 equiv.), dissolved in DMF (200 $\mu \mathrm{L})$, was added. After stirring for another $15 \mathrm{~min}$, the Boc-deprotected peptide ( $0.130 \mathrm{mmol} ; 2.0$ equiv.) was dissolved in $\operatorname{DMF}(500 \mu \mathrm{L})$ and DIPEA ( $0.286 \mathrm{mmol} ; 4.4$ equiv.) and added to the reaction mixture. The reaction was further stirred for $42 \mathrm{~h}$. The formed precipitate was removed by filtration and the product was concentrated in vacuum. Purification by column chromatography yielded the pure product. 


\section{$\left[\mathrm{Cu}\left(\mathrm{C}_{10} \mathrm{COOH}-\mathrm{VG}-\mathrm{NHC}\right)_{2}\right] \mathrm{Br}(\mathbf{2 2 a})$}

White solid; yield: $26.2 \mathrm{mg}(42 \%) ; R_{\mathrm{f}}=0.18\left(\mathrm{CHCl}_{3}-\right.$ $\mathrm{MeOH}, 20: 1)$.

IR (cm $\left.{ }^{-1}\right)$ : 3284 (s), 2923 (s), 2852 (m), 1735 (m), 1668 (s), $1631(\mathrm{~s}), 1631(\mathrm{~s}), 1544(\mathrm{~m}), 1469(\mathrm{w}), 1409(\mathrm{w}), 1387$ (w), $1341(\mathrm{w}), 1296(\mathrm{w}), 1240(\mathrm{~m}), 1152(\mathrm{w}), 1112(\mathrm{w})$, $1041(\mathrm{w}), 1013(\mathrm{w}), 846(\mathrm{w}), 674(\mathrm{~m})$.

${ }^{1} \mathrm{H} \mathrm{NMR}\left(400 \mathrm{MHz}, \mathrm{CDCl}_{3}\right): \delta=6.97\left(\mathrm{t},{ }^{3} \mathrm{~J}=5.3 \mathrm{~Hz}, 1 \mathrm{H}\right.$, $\mathrm{NH}), 6.27\left(\mathrm{~d},{ }^{3} \mathrm{~J}=8.7 \mathrm{~Hz}, 1 \mathrm{H}, \mathrm{NH}\right), 6.14(\mathrm{dd}, 2 \mathrm{H}, \mathrm{H}-$ $3+\mathrm{H}-4), 4.35$ (dd, $\left.{ }^{3} \mathrm{~J}=7.0 \mathrm{~Hz}, 1 \mathrm{H}, \mathrm{H}-11\right), 4.07+3.95$ (dd, $1 \mathrm{H}, \mathrm{H}-15), 3.72$ (s, $3 \mathrm{H}, \mathrm{H}-17), 3.56$ (m, $2 \mathrm{H}, \mathrm{H}-5)$, 3.22 (s, $3 \mathrm{H}, \mathrm{H}-1$ ), 2.20 (t, $\left.{ }^{3} \mathrm{~J}=7.6 \mathrm{~Hz}, 2 \mathrm{H}, \mathrm{H}-9\right), 2.09$ (m, $1 \mathrm{H}, \mathrm{H}-12), 1.59$ ( $\mathrm{m}, 4 \mathrm{H}, \mathrm{H}-6+\mathrm{H}-8), 1.24$ (m, $12 \mathrm{H}, \mathrm{H}-7)$, 0.94 (dd, $J=8.8,6.8 \mathrm{~Hz}, 6 \mathrm{H}, \mathrm{H}-13)$.

${ }^{13} \mathrm{C}$ NMR $\left(100 \mathrm{MHz}, \mathrm{CDCl}_{3}\right): \delta=173.3(\mathrm{C}-10), 171.8(\mathrm{C}-$ 14), 169.9 (C-16), 153.2 (C-2), 111.1 (C-4), 109.9 (C-3), $58.1(\mathrm{C}-11), 52.2(\mathrm{C}-17), 43.6(\mathrm{C}-5), 41.1(\mathrm{C}-15), 36.6(\mathrm{C}-$ 1), 31.0 (C-12), 30.3 (C-9), 29.5 (C-6), 29.3 (C-7), 29.2 (C-7), 29.2 (C-7), 29.1 (C-7), 29.1 (C-7), 26.5 (C-7), 25.6 (C-8), 19.1 (C-13), 18.2 (C-13).

\section{$\left[\mathrm{Cu}\left(\mathrm{C}_{10} \mathrm{COOH}-\mathrm{VPG}-\mathrm{NHC}\right)_{2}\right] \mathrm{Br}(\mathbf{2 2 b})$}

Colorless, sticky liquid; yield: $31.7 \mathrm{mg}(31 \%) ; R_{\mathrm{f}}=0.11$ $\left(\mathrm{CHCl}_{3}-\mathrm{MeOH}, 40: 1\right)$.

IR (cm $\left.{ }^{-1}\right)$ : $3289(\mathrm{~m}), 1926$ (s), $2854(\mathrm{~m}), 1753(\mathrm{~m}), 1629$ (s), $1531(\mathrm{~m}), 1436(\mathrm{~s}), 1369(\mathrm{~m}), 1237(\mathrm{~m}), 1201(\mathrm{~s}), 1108$ (w), $1013(\mathrm{w}), 662(\mathrm{~m})$.

${ }^{1} \mathrm{H}$ NMR (400 MHz, $\left.\mathrm{CDCl}_{3}\right): \delta=7.30\left(\mathrm{t},{ }^{3} \mathrm{~J}=4.9 \mathrm{~Hz}, 1 \mathrm{H}\right.$, $\mathrm{NH}), 6.16\left(\mathrm{~d},{ }^{3} \mathrm{~J}=9.0 \mathrm{~Hz}, 1 \mathrm{H}, \mathrm{NH}\right), 6.14(\mathrm{dd}, 2 \mathrm{H}, \mathrm{H}-$ $3+\mathrm{H}-4), 4.60$ (m, $2 \mathrm{H}, \mathrm{H}-11+\mathrm{H}-18), 3.99$ (m, 2H, H20), 3.71 (m, 5 H, H-15 + H-22), $3.55\left(\mathrm{t},{ }^{3} \mathrm{~J}=7.3 \mathrm{~Hz}, 2 \mathrm{H}\right.$, $\mathrm{H}-5), 3.22$ (s, $3 \mathrm{H}, \mathrm{H}-1), 2.33$ (m, $1 \mathrm{H}, \mathrm{H}-12), 2.18$ (t, $\left.{ }^{3} \mathrm{~J}=7.6 \mathrm{~Hz}, 2 \mathrm{H}, \mathrm{H}-9\right), 2.00$ (m, $\left.4 \mathrm{H}, \mathrm{H}-16+\mathrm{H}-17\right), 1.61$ (m, $4 \mathrm{H}, \mathrm{H}-6+\mathrm{H}-8), 1.25$ (m, $12 \mathrm{H}, \mathrm{H}-7), 0.92$ (dd, $J=23.9,6.7 \mathrm{~Hz}, 6 \mathrm{H}, \mathrm{H}-13)$.

${ }^{13} \mathrm{C}-\mathrm{NMR}\left(100 \mathrm{MHz}, \mathrm{CDCl}_{3}\right): \delta=173.1(\mathrm{C}-10), 172.3(\mathrm{C}-$ 14), 171.2 (C-19), 170.0 (C-21), 153.2 (C-2), 111.0 (C-4), 109.9 (C-3), 59.7 (C-18), 55.3 (C-11), 52.2 (C-22), 47.7 (C-15), 43.6 (C-5), 41.2 (C-20), 36.6 (C-1), $31.4(\mathrm{C}-12)$, 30.3 (C-9), 29.5 (C-6), 29.3 (C-7), 29.3 (C-7), 29.2 (C-7), 29.1 (C-7), 27.2 (C-17), 26.5 (C-7), 25.6 (C-8), 25.0 (C16), 19.4 (C-13), 17.7 (C-13).

\section{$\left[\mathrm{Cu}\left(\mathrm{C}_{10} \mathrm{COOH}-\mathrm{VPGVG}-\mathrm{NHC}\right)_{2}\right] \mathrm{Br}(\mathbf{2 2 c})$}

White solid; yield: $37.4 \mathrm{mg}(38 \%) ; R_{\mathrm{f}}=0.08\left(\mathrm{CHCl}_{3^{-}}\right.$ $\mathrm{MeOH}, 20: 1)$.

IR ( $\left.\mathrm{cm}^{-1}\right)$ : 3305 (w), 2929 (w), 2855 (w), 1754 (w), 1652 (s), $1544(\mathrm{w}), 1412$ (m), 1387 (m), $1312(\mathrm{~s}), 1206(\mathrm{w})$, $1104(\mathrm{w}), 1037(\mathrm{w}), 824(\mathrm{w}), 672(\mathrm{~m})$.

${ }^{1} \mathrm{H}$ NMR (400 MHz, DMSO-d $\left.\mathrm{d}_{6}\right): \delta=8.41\left(\mathrm{t},{ }^{3} \mathrm{~J}=5.9 \mathrm{~Hz}, 1\right.$ $\mathrm{H}, \mathrm{NH}), 8.18\left(\mathrm{t},{ }^{3} \mathrm{~J}=5.8 \mathrm{~Hz}, 1 \mathrm{H}, \mathrm{NH}\right), 7.93\left(\mathrm{~d},{ }^{3} \mathrm{~J}=8.4 \mathrm{~Hz}\right.$, $1 \mathrm{H}, \mathrm{NH}), 7.63\left(\mathrm{~d},{ }^{3} \mathrm{~J}=8.9 \mathrm{~Hz}, 1 \mathrm{H}, \mathrm{NH}\right), 6.46(\mathrm{dd}, 2 \mathrm{H}, \mathrm{H}-$ $3+\mathrm{H}-4), 4.30$ (m, $2 \mathrm{H}, \mathrm{H}-11+\mathrm{H}-22), 4.18$ (dd, $J=8.8$,
$7.0 \mathrm{~Hz}, 1 \mathrm{H}, \mathrm{H}-18), 3.81$ (m, $4 \mathrm{H}, \mathrm{H}-20+\mathrm{H}-26), 3.62$ (m, $5 \mathrm{H}, \mathrm{H}-15+\mathrm{H}-28), 3.45\left(\mathrm{t},{ }^{3} \mathrm{~J}=7.1 \mathrm{~Hz}, 2 \mathrm{H}, \mathrm{H}-5\right), 3.09(\mathrm{~s}$, $3 \mathrm{H}, \mathrm{H}-1), 2.17-1.78$ ( $\mathrm{m}, 8 \mathrm{H}, \mathrm{H}-9+\mathrm{H}-12+\mathrm{H}-16+\mathrm{H}-$ $17+\mathrm{H}-23), 1.53$ (m, $2 \mathrm{H}, \mathrm{H}-6), 1.46$ ( $\mathrm{m}, 2 \mathrm{H}, \mathrm{H}-8), 1.22$ (s, $12 \mathrm{H}, \mathrm{H}-7), 0.82$ (m, $12 \mathrm{H}, \mathrm{H}-13+\mathrm{H}-24)$.

${ }^{13} \mathrm{C}$ NMR (100 MHz, DMSO-d $\left.{ }_{6}\right): \delta=172.5(\mathrm{C}-14), 172.4$ (C-10), $171.8(\mathrm{C}-25), 170.7(\mathrm{C}-21), 170.6(\mathrm{C}-27), 169.1$ (C19), $153.0(\mathrm{C}-2), 111.7(\mathrm{C}-4), 110.6(\mathrm{C}-3), 59.9$ (C-22), 58.0 (C-18), 56.2 (C-11), 52.1 (C-28), 47.6 (C-15), 43.0 (C$5+\mathrm{C}-20), 41.0(\mathrm{C}-26), 35.3(\mathrm{C}-1), 31.0(\mathrm{C}-23), 30.3(\mathrm{C}-12)$, 30.2 (C-9), 29.7 (C-17), 29.4 (C-6), 29.3 (C-7), 29.1 (C-7), 29.0 (C-7), 29.0 (C-7), 26.4 (C-7), 25.7 (C-8), 24.9 (C-16), 19.6 (C-24), 19.5 (C-13), 19.0 (C-24), 18.5 (C-13).

\section{$\left[\mathrm{Cu}\left(\mathrm{C}_{10} \mathrm{COOH}-(\mathrm{VPGVG})_{2}-\mathrm{NHC}\right)_{2}\right] \mathrm{Br}$ (22d)}

White solid; yield: $32.7 \mathrm{mg}(11 \%) ; R_{\mathrm{f}}=0.26$ (DCM$\mathrm{MeOH}, 10: 1)$.

IR ( $\left.\mathrm{cm}^{-1}\right)$ : 3288 (w), 2931 (w), 1648 (s), $1526(\mathrm{~m}), 1445$ (w), $1202(\mathrm{w}), 1130(\mathrm{w}), 836(\mathrm{w}), 800(\mathrm{w}), 720(\mathrm{w})$.

${ }^{1} \mathrm{H} \mathrm{NMR}\left(400 \mathrm{MHz}\right.$, DMSO-d $\left.\mathrm{d}_{6}\right): \delta=8.41\left(\mathrm{t},{ }^{3} \mathrm{~J}=5.9 \mathrm{~Hz}, 1\right.$ $\mathrm{H}, \mathrm{NH}), 8.21(\mathrm{~m}, 3 \mathrm{H}, \mathrm{NH}), 7.95\left(\mathrm{t},{ }^{3} \mathrm{~J}=8.1 \mathrm{~Hz}, 2 \mathrm{H}, \mathrm{NH}\right)$, $7.64\left(\mathrm{~d},{ }^{3} \mathrm{~J}=8.9 \mathrm{~Hz}, 1 \mathrm{H}, \mathrm{NH}\right), 6.45(\mathrm{dd}, 2 \mathrm{H}, \mathrm{H}-3+\mathrm{H}-4)$, 4.30 ( $\mathrm{m}, 4 \mathrm{H}, \mathrm{H}-11+\mathrm{H}-22), 4.15$ ( $\mathrm{m}, 2 \mathrm{H}, \mathrm{H}-18), 3.73$ (m, $10 \mathrm{H}, \mathrm{H}-15+\mathrm{H}-20+\mathrm{H}-26), 3.62(\mathrm{~m}, 5 \mathrm{H}, \mathrm{H}-15+\mathrm{H}-$ 28), 3.45 (t, $\left.{ }^{3} \mathrm{~J}=7.1 \mathrm{~Hz}, 2 \mathrm{H}, \mathrm{H}-5\right), 3.09$ ( $\left.\mathrm{s}, 3 \mathrm{H}, \mathrm{H}-1\right)$, 2.18-1.79 (m, $14 \mathrm{H}, \mathrm{H}-9+\mathrm{H}-12+\mathrm{H}-16+\mathrm{H}-17+\mathrm{H}-$ 23), 1.53 ( $\mathrm{m}, 2 \mathrm{H}, \mathrm{H}-6), 1.46$ ( $\mathrm{m}, 2 \mathrm{H}, \mathrm{H}-8), 1.21$ (s, $12 \mathrm{H}$, $\mathrm{H}-7), 0.84(\mathrm{~m}, 24 \mathrm{H}, \mathrm{H}-13+\mathrm{H}-24)$.

${ }^{13} \mathrm{C}$ NMR $\left(100 \mathrm{MHz}, \mathrm{DMSO}-\mathrm{d}_{6}\right): \delta=172.1(\mathrm{C}-14), 171.9$ (C-14), 171.9 (C-10), 171.3 (C-25), 171.0 (C-25), 170.5 (C-19), 170.1 (C-19), 169.8 (C-27), 168.6 (C27), $168.6(\mathrm{C}-21), 168.6$ (C-21), 152.5 (C-2), 111.3 (C4), 110.1 (C-3), 59.6 (C-22), 59.5 (C-22), 58.1 (C-18), 57.5 (C-18), 55.8 (C-11), 55.7 (C-11), $51.6(\mathrm{C}-28), 47.3$ (C-15), 47.2 (C-15), 42.5 (C-5 + C-20), 40.5 (C-26), 40.2 (C-26), 34.9 (C-1), 30.5 (C-23), 30.1 (C-12), 29.9 (C-12), 29.8 (C-9), 29.2 (C-17), 29.2 (C-17), 28.9 (C6), 28.8 (C-7), 28.7 (C-7), 28.6 (C-7), 28.5 (C-7), 25.9 (C-7), 25.3 (C-8), 24.4 (C-16), 24.4 (C-16), 19.1 (C24), 19.0 (C-13), 18.6 (C-24), 18.4 (C-13), 18.3 (C-24), $18.0(\mathrm{C}-13)$.

\section{$\left[\mathrm{Cu}\left(\mathrm{C}_{10} \mathrm{COOH}-(\mathrm{VPGVG})_{4}-\mathrm{NHC}\right)_{2}\right] \mathrm{Br}(\mathbf{2 2 e})$}

Yellow solid; yield: $107 \mathrm{mg}(14 \%), R_{\mathrm{f}}=0.18$ (DCM$\mathrm{MeOH}, 5: 1)$.

IR ( $\left.\mathrm{cm}^{-1}\right)$ : 3285 (w), $2964(\mathrm{w}), 1752(\mathrm{w}), 1620(\mathrm{~s}), 1523$ (m), 1443 (w), $1202(\mathrm{w}), 1131(\mathrm{w}), 1034(\mathrm{w}), 660(\mathrm{w})$. ${ }^{1} \mathrm{H}$ NMR (400 MHz, DMSO-d $\left.{ }_{6}\right): \delta=8.40\left(\mathrm{t},{ }^{3} \mathrm{~J}=5.9 \mathrm{~Hz}, 2\right.$ $\mathrm{H}, \mathrm{NH}), 8.18(\mathrm{~m}, 6 \mathrm{H}, \mathrm{NH}), 7.92(\mathrm{~m}, 4 \mathrm{H}, \mathrm{NH}), 7.62$ (d, $\left.{ }^{3} \mathrm{~J}=8.8 \mathrm{~Hz}, 4 \mathrm{H}, \mathrm{NH}\right), 6.44(\mathrm{dd}, 2 \mathrm{H}, \mathrm{H}-3+\mathrm{H}-4), 4.30(\mathrm{~m}$, $8 \mathrm{H}, \mathrm{H}-11+\mathrm{H}-22), 4.12(\mathrm{~m}, 4 \mathrm{H}, \mathrm{H}-18), 3.72(\mathrm{~m}, 20 \mathrm{H}, \mathrm{H}-$ $15+\mathrm{H}-20+\mathrm{H}-26), 3.60(\mathrm{~m}, 7 \mathrm{H}, \mathrm{H}-15+\mathrm{H}-28), 3.43$ (m, $2 \mathrm{H}, \mathrm{H}-5), 3.07$ (s, $3 \mathrm{H}, \mathrm{H}-1)$, 2.18-1.72 (m, $26 \mathrm{H}, \mathrm{H}-$ 
$9+\mathrm{H}-12+\mathrm{H}-16+\mathrm{H}-17+\mathrm{H}-23), 1.49$ (m, $2 \mathrm{H}, \mathrm{H}-6)$, 1.43 (m, 2 H, H-8), 1.20 (s, 12 H, H-7), 0.82 (m, 48 H, H$13+\mathrm{H}-24)$.

Synthesis of Benzyl Azide (23)

Sodium azide (5.5 g, $84.7 \mathrm{mmol}$ ) and benzyl bromide (13.2 g, $9.17 \mathrm{~mL}, 77.0 \mathrm{mmol}$ ) were dissolved in DMSO $(170.0 \mathrm{~mL})$. The reaction mixture was stirred at $40{ }^{\circ} \mathrm{C}$ for $90 \mathrm{~h}$. Afterwards water $(50.0 \mathrm{~mL})$ was added and the reaction was further stirred, until it cooled down to room temperature. The mixture was extracted with $\mathrm{Et}_{2} \mathrm{O}$ $(3 \times 30.0 \mathrm{~mL})$ and the combined organic phases were washed with water $(2 \times 50.0 \mathrm{~mL})$ and brine $(50.0 \mathrm{~mL})$. Subsequently the organic phase was dried over $\mathrm{Na}_{2} \mathrm{SO}_{4}$, filtered, and the solvent was removed under reduced pressure.

Yellow solution; yield: $9.45 \mathrm{~g}$ (92\%).

IR: $v_{\max }\left(\mathrm{cm}^{-1}\right)$ : $3032(\mathrm{w}), 2090(\mathrm{~s}), 1496(\mathrm{w}), 1454(\mathrm{w})$, 1349 (w), 1253 (m), 1201 (w), 1077 (w), 1028 (w), 875 (w), $736(\mathrm{~m}), 697(\mathrm{~s}), 651(\mathrm{w}), 566(\mathrm{w})$.

${ }^{1} \mathrm{H} \mathrm{NMR}\left(400 \mathrm{MHz}, \mathrm{CDCl}_{3}\right): \delta=7.38(\mathrm{~m}, 5 \mathrm{H}, \mathrm{H}-3+\mathrm{H}-$ $4+\mathrm{H}-5), 4.35$ (s, $2 \mathrm{H}, \mathrm{H}-1)$.

${ }^{13} \mathrm{C} \mathrm{NMR}\left(100 \mathrm{MHz}, \mathrm{CDCl}_{3}\right): \delta=135.4(\mathrm{C}-2), 129.0(\mathrm{C}-4)$, 128.3 (C-5), 128.2 (C-3), 54.8 (C-1).

\section{Funding Information}

The authors are thankful for grants from the Sonderforschungsbereich/Transregio (SFB/TRR) 102 (TP A03 and A12) and the DFG (grant within the SPP 1568). The authors also thank the Leistungszentrum "System- und Biotechnologie" (Uni-CBS1) for financial support for the project "Biologisch abbaubare Partikel über Enkapsulierungsmethoden: Emulsions-/Evaporationsverfahren und 3D-Printing".

\section{Acknowledgments}

The authors thank MSc Jan Freudenberg for assistance during the CD and IR measurements in solution and Dr. Philipp Michael for helpful discussions and critical remarks while preparing the manuscript.

\section{Supporting Information}

Supporting information for this article is available online at https://doi.org/10.1055/s-0040-1702149.

\section{References}

(1) Anwar, R. A. Biochem. Educ. 1990, 18, 162.

(2) Li, B.; Daggett, V. J. Muscle. Res. Cell Motil. 2002, 23, 561.

(3) Keeley, F. W.; Bellingham, C. M.; Woodhouse, K. A. Philos. Trans. R. Soc. London, Ser. B 2002, 357, 185.
(4) Daamen, W. F.; Veerkamp, J. H.; van Hest, J. C. M.; van Kuppevelt, T. H. Biomaterials 2007, 28, 4378.

(5) Perticaroli, S.; Ehlers, G.; Jalarvo, N.; Katsaras, J.; Nickels, J. D. J. Phys. Chem. Lett. 2015, 6, 4018.

(6) Foster, J. A.; Bruenger, E.; Gray, W. R.; Sandberg, L. B. J. Biol. Chem. 1973, 248, 2876.

(7) Urry, D. W.; Cunningham, W. D.; Ohnishi, T. Biochemistry 1974, $13,609$.

(8) Sandberg, L. B.; Leslie, J. G.; Leach, C. T.; Alvarez, V. L.; Torres, A. R.; Smith, D. W. Pathol. Biol. 1985, 33, 266.

(9) Yeh, H.; Ornstein-Goldstein, N.; Indik, Z., et al. Coll. Relat. Res. 1987, 7, 235.

(10) Urry, D. W.; Long, M. M. CRC Crit. Rev. Biochem. 1976, 4, 1.

(11) Venkatachalam, C. M.; Urry, D. W. Macromolecules 1981, 14, 1225.

(12) Urry, D. W.; Trapane, T. L.; Long, M. M.; Prasad, K. U.J. Chem. Soc., Faraday Trans. 1983, 79, 853.

(13) Urry, D. W.; Venkatachalam, C. M. Int. J. Quantum Chem. 1983, $24,81$.

(14) Urry, D. W. J. Protein Chem. 1988, 7, 1.

(15) Urry, D. W. J. Protein Chem. 1988, 7, 81.

(16) Urry, D. W.; Long, M. M.; Ohnishi, T.; Jacobs, M. Biochem. Biophys. Res. Commun. 1974, 61, 1427.

(17) Khaled, M. A.; Venkatachalam, C. M.; Sugano, H.; Urry, D. W. Int. J. Pept. Protein Res. 1981, 17, 23.

(18) Urry, D. W.; Trapane, T. L.; Sugano, H.; Prasad, K. U. J. Am. Chem. Soc. 1981, 103, 2080.

(19) Tunn, I.; de Léon, A. S.; Blank, K. G.; Harrington, M. J. Nanoscale 2018, 10, 22725.

(20) López-García, P.; Goktas, M.; Bergues-Pupo, A. E.; Koksch, B.; Varón Silva, D.; Blank, K. G. Phys. Chem. Chem. Phys. 2019, 21, 9145.

(21) Davis, D. A.; Hamilton, A.; Yang, J.; Cremar, L. D.; Van Gough, D.; Potisek, S. L.; Ong, M. T.; Braun, P. V.; Martínez, T. J.; White, S. R.; Moore, J. S.; Sottos, N. R. Nature 2009, 459, 68.

(22) Beiermann, B. A.; Davis, D. A.; Kramer, S. L. B.; Moore, J. S.; Sottos, N. R.; White, S. R. J. Mater. Chem. 2011, 21, 8443.

(23) Zhang, H.; Chen, Y.; Lin, Y.; Fang, X.; Xu, Y.; Ruan, Y.; Weng, W. Macromolecules 2014, 47, 6783.

(24) Chen, Y.; Sijbesma, R. P. Macromolecules 2014, 47, 3797.

(25) Clough, J. M.; Balan, A.; van Daal, T. L. J.; Sijbesma, R. P. Angew. Chem. Int. Ed. 2016, 55, 1445.

(26) Piermattei, A.; Karthikeyan, S.; Sijbesma, R. P. Nat. Chem. 2009, 1, 133.

(27) Jakobs, R. T. M.; Sijbesma, R. P. Organometallics 2012, 31, 2476.

(28) Michael, P.; Binder, W. H. Angew. Chem. Int. Ed. 2015, 54, 13918.

(29) Michael, P.; Sheidaee Mehr, S. K.; Binder, W. H. J. Polym. Sci., Part A: Polm. Chem. 2017, 55, 3893.

(30) Di Giannantonio, M.; Ayer, M. A.; Verde-Sesto, E.; Lattuada, M.; Weder, C.; Fromm, K. M. Angew. Chem. Int. Ed. 2018, 57, 11445.

(31) Michael, P.; Biewend, M.; Binder, W. H. Macromol. Rapid Commun. 2018, 39, e1800376.

(32) Sha, Y.; Zhang, Y.; Xu, E.; Wang, Z.; Zhu, T.; Craig, S. L.; Tang, C. ACS Macro Lett. 2018, 7, 1174.

(33) Biewend, M.; Neumann, S.; Michael, P.; Binder, W. H. Polym. Chem. 2019, 10, 1078.

(34) Sha, Y.; Zhang, Y.; Xu, E.; McAlister, C. W.; Zhu, T.; Craig, S. L.; Tang, C. Chem. Sci. 2019, 10, 4959.

(35) Hickenboth, C. R.; Moore, J. S.; White, S. R.; Sottos, N. R.; Baudry, J.; Wilson, S. R. Nature 2007, 446, 423.

(36) Larsen, M. B.; Boydston, A. J. J. Am. Chem. Soc. 2013, 135, 8189.

(37) Larsen, M. B.; Boydston, A. J. J. Am. Chem. Soc. 2014, 136, 1276. 
(38) Diesendruck, C. E.; Steinberg, B. D.; Sugai, N.; Silberstein, M. N.; Sottos, N. R.; White, S. R.; Braun, P. V.; Moore, J. S. J. Am. Chem. Soc. 2012, 134, 12446.

(39) Kean, Z. S.; Craig, S. L. Polymer 2012, 53, 1035.

(40) Van Der Hoff, B. M. E.; Glynn, P. A. R. J. Macromol. Sci. Part A Pure Appl. Chem. 1974, 8, 429.

(41) Van der Hoff, B. M. E.; Gall, C. E. J. Macromol. Sci. Part A Pure Appl. Chem. 1977, 11, 1739.

(42) Funtan, S.; Michael, P.; Binder, W. H. Biomimetics 2019, 4, 24.

(43) Chen, Y.; Guan, Z. J. Am. Chem. Soc. 2010, 132, 4577.

(44) Kong, J.; Yu, S. Acta Biochim. Biophys. Sin. 2007, 39, 549.

(45) Serrano, V.; Liu, W.; Franzen, S. Biophys. J. 2007, 93, 2429.
(46) Greenfield, N. J. Nat. Protoc. 2006, 1, 2876.

(47) Binder, W. H.; Sachsenhofer, R. Macromol. Rapid Commun. 2008, 29, 952.

(48) Tisato, F.; Marzano, C.; Porchia, M.; Pellei, M.; Santini, C. Med. Res. Rev. 2010, 30, 708.

(49) Gandin, V.; Porchia, M.; Tisato, F.; Zanella, A.; Severin, E.; Dolmella, A.; Marzano, C. J. Med. Chem. 2013, 56, 7416.

(50) Li, F.; Bravo-Rodriguez, K.; Phillips, C.; Seidel, R. W.; Wieberneit, F.; Stoll, R.; Doltsinis, N. L.; Sanchez-Garcia, E.; Sander, W. J. Phys. Chem. B 2013, 117, 3560.

(51) Maity, S.; Kumar, P.; Haldar, D. Soft Matter. 2011, 7, 5239. 